US Army Corps

of Engineers:

Portland District

Prepared for the U.S. Army Corps of Engineers, Portland District.

under a Government Order with the U.S. Department of Energy

Contract DE-AC05-76RL01830

\title{
Characterization of Gatewell Orifice Lighting at the Bonneville Dam Second Powerhouse and Compendium of Research on Light Guidance with Juvenile Salmonids
}

\author{
FINAL REPORT
}

RP Mueller

MA Simmons

September 2008 


\title{
DISCLAIMER
}

This report was prepared as an account of work sponsored by an agency of the United States Government. Neither the United States Government nor any agency thereof, nor Battelle Memorial Institute, nor any of their employees, makes any warranty, express or implied, or assumes any legal liability or responsibility for the accuracy, completeness, or usefulness of any information, apparatus, product, or process disclosed, or represents that its use would not infringe privately owned rights. Reference herein to any specific commercial product, process, or service by trade name, trademark, manufacturer, or otherwise does not necessarily constitute or imply its endorsement, recommendation, or favoring by the United States Government or any agency thereof, or Battelle Memorial Institute. The views and opinions of authors expressed herein do not necessarily state or reflect those of the United States Government or any agency thereof.

\author{
PACIFIC NORTHWEST NATIONAL LABORATORY \\ operated by \\ BATTELLE \\ for the \\ UNITED STATES DEPARTMENT OF ENERGY \\ under Contract DE-AC05-76RL01830 \\ Printed in the United States of America \\ Available to DOE and DOE contractors from the \\ Office of Scientific and Technical Information, \\ P.O. Box 62, Oak Ridge, TN 37831-0062; \\ ph: (865) 576-8401 \\ fax: (865) 576-5728 \\ email: reports@adonis.osti.gov
}

\author{
Available to the public from the National Technical Information Service, \\ U.S. Department of Commerce, 5285 Port Royal Rd., Springfield, VA 22161 \\ ph: (800) 553-6847 \\ fax: (703) 605-6900 \\ email: orders@ntis.fedworld.gov \\ online ordering: http://www.ntis.gov/ordering.htm
}




\section{Characterization of Gatewell Orifice Lighting at the Bonneville Dam Second Powerhouse and Compendium of Research on Light Guidance with Juvenile Salmonids}

\section{Final Report}

RP Mueller

MA Simmons

September 2008

Prepared for the

U.S. Army Corps of Engineers, Portland District, under a Government Order with the

U.S. Department of Energy

Contract DE-AC05-76RL01830

Pacific Northwest National Laboratory

Richland, Washington 99352 


\section{Summary}

The study described in this report was conducted by the Pacific Northwest National Laboratory (PNNL) to provide biologist and engineers of the U.S. Army Corps of Engineers (USACE) with general design guidelines for using artificial lighting to enhance the passage of juvenile salmonids into the collection channel at the Bonneville Dam second powerhouse, managed by the USACE Portland District. The work comprised three primary objectives. The first was to review and synthesize all relevant studies in which artificial light was evaluated in a field or laboratory setting for its potential to guide fish at passage barriers within juvenile salmonid outmigration corridors. The second objective was to conduct a field study at the Bonneville Dam second powerhouse to evaluate the output levels of two artificial light sources at one orifice entrance within Gatewell 12. The third objective was to compare, in a laboratory setting, the performance of three light sources in terms of light intensity values.

PNNL reviewed 36 sources in the published gray and peer-reviewed literature and prepared a synopsis that includes the study objectives, species and life stage, experimental conditions, type of lighting used, and a summary of the results. We found that artificial lighting has been used in two general applications: 1) as a means to induce avoidance behavior by altering the fishes' swimming pathway and 2 ) as a guidance or attraction avenue to assist fish in locating safe passage routes. The literature review indicated that several factors play a combined role in the fishes' ability to safely navigate passage barriers. These factors include genetic makeup (species and subspecies), life stage, season, time of day, light levels, presence of predators, distance to cover, water temperature, group size, noise regime, and water current.

Our review determined that juvenile salmonids can be attracted to illuminated regions during nocturnal periods and can perceive light levels down to approximately 0.25 lux or $10^{-2} \mathrm{ft}$-c, equivalent to the light produced by moonlight. At the other end of the spectrum, we found that juvenile salmonids generally avoid or are startled when exposed to more intense light levels that correspond to daylight conditions or near 400 lux $\left(10^{-1.5} \mathrm{ft}-\mathrm{c}\right)$. To guide fish through manmade structures using artificial lights requires an understanding of the types of illumination and the nature of salmonid light perception. To respond to a light source, the fish visual system must be able to respond to the appropriate wavelengths that correspond to peaks in the spectral response of the photo receptors in the eye. Studies that have examined the use of artificial light to guide salmonids safely through migration barriers such as hydroelectric dams show measurable differences in juvenile responses to both the quantity and quality of the light stimulus. Our literature review concluded that any fish passage guidance structure must be based on an understanding of fish behavior and environmental and hydraulic conditions at the specific location.

Our field study at the Bonneville Dam second powerhouse (B2) found the existing lighting conditions at the orifice tubes in the downstream migration channel to be less than ideal to illuminate the entrance of the orifice. Based on our review of the lighting studies, a minimum luminance value of approximately 200-300 lux is needed at the orifice entrance. While some studies, in controlled laboratory experiments, have shown that this light intensity could possibly startle test fish (if exposure is sudden), light intensity values are expected to decrease rapidly within a short distance from the orifice. High water turbidity present for much of the spring outmigration period in the Columbia River also would play a role in decreasing light intensity at the orifice. 
Field measurements of light intensity from light-emitting diode (LED) light bulbs at a single orifice in Gatewell 12 were low, at approximately 0.1 lux with a water-scaled lens. Light output for a 90-W halogen light with a water-scaled lens was 0.25 lux at the opening. When the water-scaled lens was exchanged for a new lens, the readings increased to 0.6 lux for the LEDs and 3.25 lux for the halogen light. For comparison, 1 lux is the amount of light produced by moonlight at high altitude, and 10 lux is the intensity of a candle at a distance of $1 \mathrm{ft}$. The halogen lights were far more effective at producing illumination near the orifice regions and outward to approximately 16 in. on axis with the opening, where the values were similar to the ambient light background measurements. The LEDs were less effective at illuminating the region; this was especially evident when the water-scaled lens was used. Both light sources produced light levels below effective minimum luminance values noted in the literature.

The laboratory tests were conducted at the PNNL Aquatic Research Laboratory in Richland, Washington. We measured the light output from halogen spotlights and mercury vapor lamps as well as the LED lamps currently in use at the B2. Our results using a water-scaled glass lens showed that the light loss for the halogen and the aqua green LED lamp was 5-6 times higher than the loss with a clean lens. Output from a mercury vapor lamp when the water-scaled lens cap was placed at the light face was reduced by only a factor of two. The drawback to using the mercury vapor and the halogen lamps is the amount of heat produced by the lens $\left(250^{\circ} \mathrm{F}\right.$ for the mercury vapor and $143^{\circ} \mathrm{F}$ for the halogen) and the reduced bulb life as compared to the LEDs.

Based on our study, some options for improving the lighting at the orifice entrances at the B2 include the following:

- Incorporate a ring of LEDs that would be recessed into the orifice opening, thus eliminating the need for the light tubes. An automated cleaning system also would be required.

- Incorporate the light source into the lens cap so that the cap and light housing is one waterproof unit. This would allow for all of the light to be directed into the light tube and eliminate the water scaling and debris-buildup issue, although water buildup still could pose a problem due to the splashing of water upward into the light tubes. Cleaning of the light and cap assembly also would be simplified.

- Use a white emitted light source that has a minimum luminance value of approximately 200-300 lux near the immediate orifice entrance.

- Incorporate higher-intensity LED lamps. Several manufactures have developed high-output LEDS that have been used in a variety of applications, including automobiles, flashlights, and residential and industrial interior and exterior lighting. These relatively new modules provide almost 50\% more light (some up to 250 lux) than a standard 5-W LED bulb. Models of the cool white version have an expected 50,000-hour lifespan and have peak wavelengths of 440 and 550 nanometers.

To evaluate the effectiveness of any modification to the existing system, tests could be conducted in which tagged fish are released in the gatewell with a light-on/light-off scenario and the orifice passage efficiency evaluated. Different lighting sources could be tested to determine if white light or light emitted within the peak action spectra of juvenile salmonids (blue-green region) is best for attracting fish near the orifice where the flow component is sufficient for entrainment into the collection channel. 


\section{Acknowledgments}

Funding for this project was provided by the U.S. Army Corps of Engineers (USACE), Portland District. Dennis Schwartz was the technical contracting officer, and Jonathan Rerecich and Tammy Mackey from the USACE helped coordinate work at Bonneville Dam. We thank Shon Zimmerman, Pacific Northwest National Laboratory (PNNL) Bonneville Field Office, for his assistance with the field study. Dr. Richard Brown, PNNL, served as the technical peer reviewer for this report. 


\section{Contents}

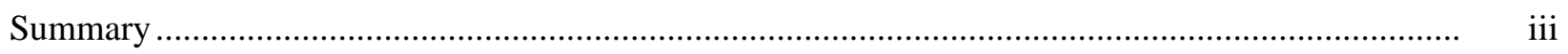

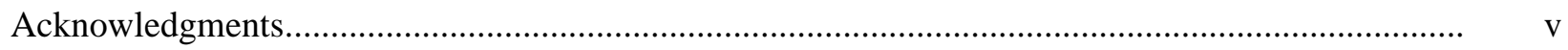

Abbreviations and Acronyms ................................................................................................. ix

Glossary of Light Measurement Terminology ...................................................................... xi

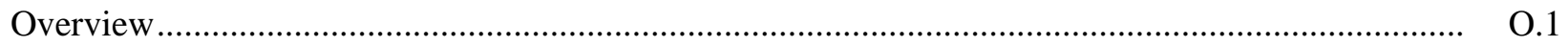

Chapter 1 Compendium of Research on Using Artificial Light To Guide Juvenile Salmonids -

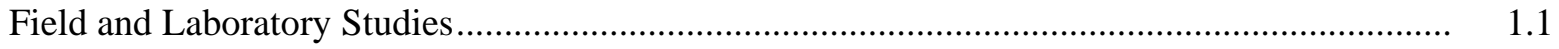

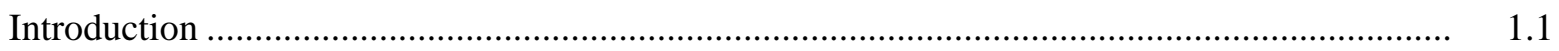

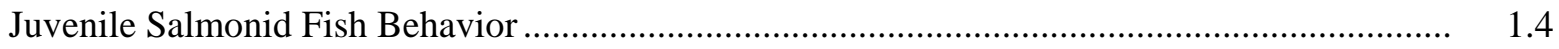

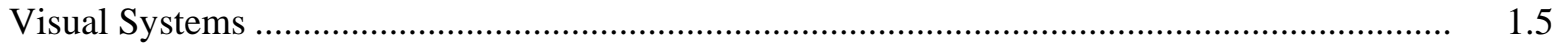

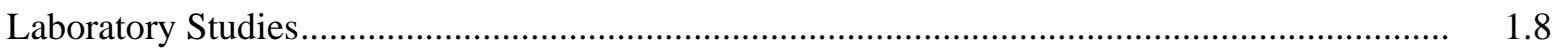

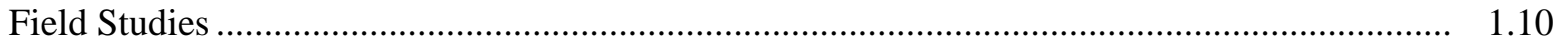

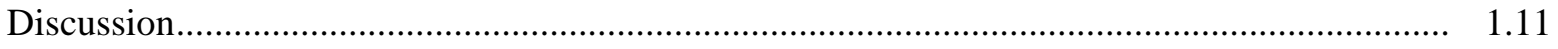

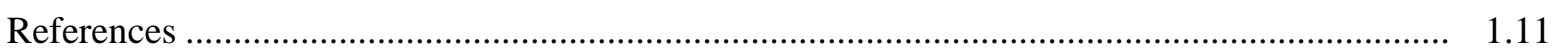

Chapter 2 Field and Laboratory Tests of Lights and Light Intensities with Reference to Use in Gatewell Orifice Structures at the Bonneville Dam Second Powerhouse .................................. 2.1

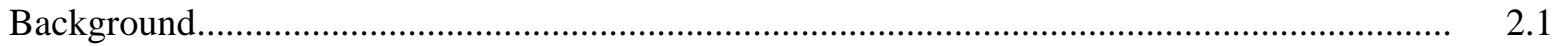

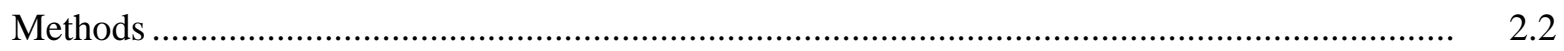

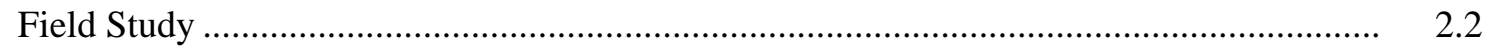

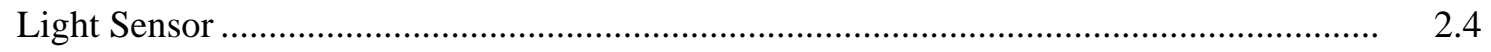

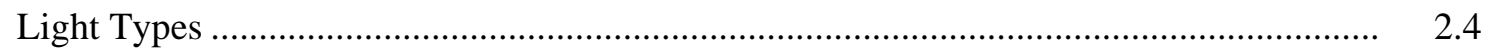

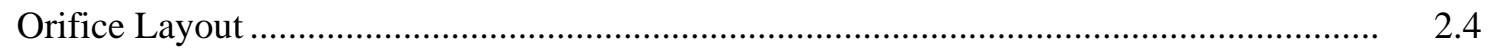

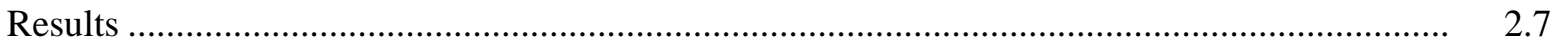

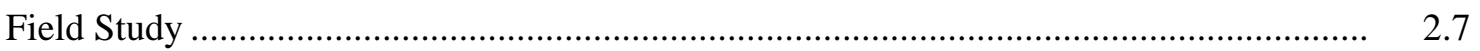

Orifice Lighting Characterization ....................................................................... 2.7

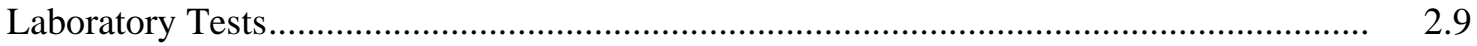

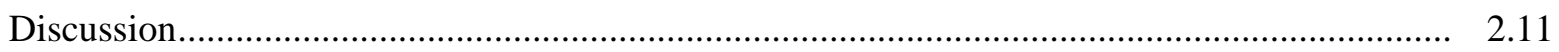

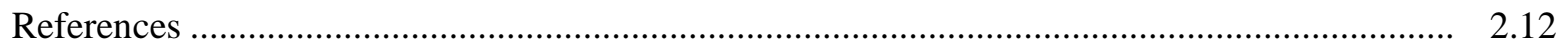

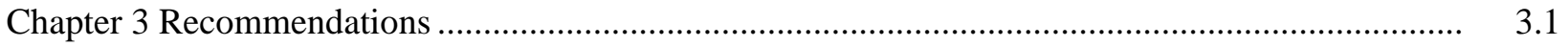

Appendix - Synopsis of Literature Reviewed ........................................................................... A.1 


\section{Figures}

1.1 Life cycle of anadromous Pacific salmon showing major developmental stages ........................ 1.2

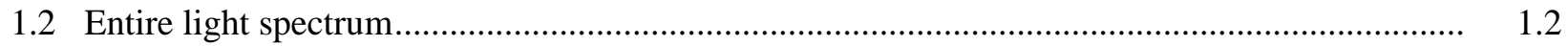

1.3 Visible color light spectrum and associated wavelengths....................................................... 1.2

1.4 Average action spectra of six juvenile rainbow trout in a controlled laboratory experiment ....... 1.3

1.5 Response of juvenile Pacific salmon to various light intensities and the relationship to ambient light

2.1 Cross section of a typical Columbia River hydroelectric project illustrating the mechanical bypass system

2.2 Support frame and weighted trolley used to deploy light sensor in Gatewell 12A..................... 2.3

2.3 Light-emitting diode light installed above light tube at Orifice 12A South .............................. 2.3

2.4 Light sensor attached to trolley with underwater camera for position verification ..................... 2.4

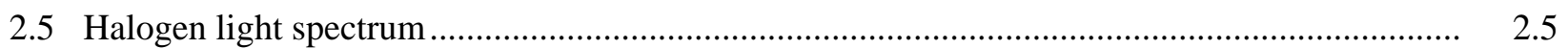

2.6 Dewatered closed orifice at north end of Gatewell 13B showing light tubes at orifice entrance.

2.7 Top portion of light tubes in downstream migration channel with halogen lights installed......... 2.7

2.8 Ambient light levels measured within covered Gatewell 12A at various water depths............... 2.8

2.9 Light intensity measured at center of south orifice in Gatewell 12A for both light-emitting diode and halogen lamps using the clean and dirty lens caps...

2.10 Light intensity measured 6 in. above top of south orifice in Gatewell 12A for both lightemitting diode and halogen lamps using the clean and dirty lens caps.

2.11 Light intensity with light sensor 12 in. from south end of orifice, sensor pointed toward north.. 2.10

2.12 Water-scaled orifice tube lens cover. 2.11

\section{Tables}

1.1 Common and scientific names for Pacific Northwest salmon and trout used in light studies ...... $\quad 1.1$

1.2 Light levels in lux and foot-candles for various levels of daylight............................................ 1.3

1.3 Comparison of the maximum spectral sensitivity of the photopic mechanisms in salmonids...... $\quad 1.7$

2.1 Characteristics of light-emitting diode and halogen lights tested at B2 collection channel at Bonneville Dam in 2007

2.2 Laboratory tests using three light sources in air and with light sensor in water using clean and water-scaled lens at light face 


\section{Abbreviations and Acronyms}

B2

cd

cfs

deg

DSM

EPRI

$\mathrm{ft}$

$\mathrm{ft}-\mathrm{c}$

in.

$\mathrm{lb}$

LED

$\mathrm{m}$

$\mathrm{mm}$

$\mathrm{nm}$

NTU

OPE

PAR

PIT

PNNL

USACE

UV

W
Bonneville Dam second powerhouse

candela

cubic feet per second

degree(s)

downstream migration (channel)

Electric Power Research Institute

foot, feet

foot-candle(s)

inch(es)

pound(s)

light-emitting diode

meter(s)

millimeter(s)

nanometer(s)

nephelometric turbidity unit(s)

orifice passage efficiency

photosynthetically active radiation

passive integrated transponder

Pacific Northwest National Laboratory

U.S. Army Corps of Engineers

ultraviolet

watt(s) 


\section{Glossary of \\ Light Measurement Terminology}

candela The unit of luminous intensity. One candela is defined as the luminous intensity of $1 / 600,000$ square meter of projected area of a blackbody radiator operating at the temperature of solidification of platinum under pressure of 101,325 newtons per square meter.

foot-candle A measure of light intensity; the amount of light received by 1 square foot of a surface that is 1 foot from a point source of light equivalent to one candle of a certain type (see illustration).

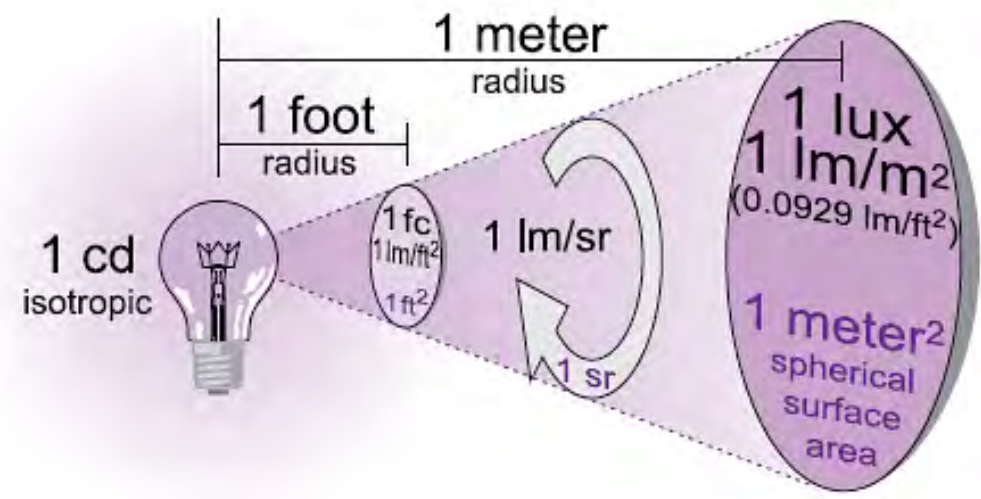

Irradiance (from http://www.intl-lighttech.com/services/light-measurement-handbook)

end foot- $\quad$ End foot-candle measurements are based on the focused light beam only. The spherical candle energy or surrounding light output is not captured by or reflected back to the surface of the foot-candle light meter. End foot-candle is the focal light beam measurement from point A to point $\mathrm{B}$ at a 1 -foot distance.

lumen A unit of light flow or luminous flux. The lumen rating of a lamp is a measure of the total light output of the lamp. The most common measurement of light output (or luminous flux) is the lumen. That is, 1000 lumens, concentrated into an areas of 1 square meter, lights up that square meter with an illuminance of 1000 lux. The same 1000 lumens spread out over 10 square meters produce only 100 lux.

end lumens End lumens measurements are based on a spot of light only. The spherical energy or surrounding light output is not captured by or reflected back to the surface of the lumen light meter. End lumens is the light measurement from point A to point B at a 1-foot distance. 
luminance Luminous flux (light output); the quantity of light that leaves the lamp, measured in lumens. Lamps are rated in both initial and mean lumens:

- Initial lumens indicate how much light is produced once the lamp has stabilized; for fluorescent and high-intensity discharge lamps, this is typically 100 hours.

- Mean lumens indicate the average light output over the lamp's rated life, which reflects the gradual deterioration of performance due to the rigors of continued operation; for fluorescent lamps, this is usually determined at $40 \%$ of rated life.

illuminance The intensity or degree to which something is illuminated as measured in lux or footcandles.

lux The metric unit of measure for illuminance of a surface. One lux is equal to 1 lumen per square meter. One lux equals 0.0929 foot-candle.

light level Light intensity measured on a plane at a specific location is called illuminance.

Illuminance is measured in foot-candles, which are workplane lumens per square foot.

efficacy of The total light output of a light source divided by the total power input. Efficacy is

a light expressed in lumens per watt.

source

radiance How much energy is released from a specific light source.

watt The unit of measuring electrical power. Wattage does not relate to the light output level. It defines the rate of energy consumption by an electrical device when it is in operation. The energy cost of operating an electrical device is calculated as its wattage time in hours of use. 


\section{Overview}

The goal of the study described in this report was to provide U.S. Army Corps of Engineers (USACE) biologists and engineers with general design guidelines for using artificial lighting to enhance the passage of juvenile salmonids into the collection channel at the Bonneville Dam second powerhouse (B2). The study was conducted during fall 2007 by researchers at the Pacific Northwest National Laboratory (PNNL) for the USACE Portland District.

The specific objectives for this study were to

1. Review and synthesize existing lighting data for juvenile salmonid attraction and deterrence and how the data are used at fish bypass facilities.

2. Evaluate current B2 orifice lighting conditions with both light-emitting diode (LED) and halogen lighting sources.

3. Conduct laboratory tests to measure the light output of halogen spotlights and mercury vapor lamps as well as the LED lamps currently in use at the B2 orifices.

4. Provide the USACE with recommendations as to what lighting intensity, source, and configuration would improve fish passage at the B2 orifices.

In this report, Chapter 1 provides PNNL's synthesis of the relevant literature related to light and fish guidance for both field and laboratory studies. Chapter 2 presents a description of the PNNL field measurements of light levels at one B2 orifice through which fish must pass to reach the fish collection channel. Two light types were evaluated-LED lights and halogen spotlights. Additional measurements with mercury lamps were made at the PNNL Aquatic Research Laboratory in Richland, Washington, to determine baseline intensity of the current lighting. Recommendations based on the study are offered in Chapter 3. An Appendix presents a tabulated synopsis of literature reviewed as part of this study. 


\title{
Chapter 1
}

\section{Compendium of Research on Using Artificial Light To Guide Juvenile Salmonids - Field and Laboratory Studies}

\author{
Mary Ann Simmons and Robert P. Mueller
}

\section{Introduction}

The objective of this task was to review the available literature on the response of juvenile salmonids to light, specifically to lights used as guidance at hydroelectric facilities. We further focused the review on non-strobe light sources such as incandescent and mercury vapor lights. The Appendix to this report provides a synopsis of the literature reviewed in table format.

Reviews of the response of fish to lights have found a range of responses, from no response to attraction and repulsion. Factors affecting the response appear to be species, age, previous light exposure, and light source.

Table 1.1 contains a list of species studied in the reviewed sources. Two common names are listed for Oncorhynchus nerka and O. mykiss; the first is the anadromous species, the second the freshwater counterpart. Figure 1.1 shows the various developmental stages for anadromous Pacific salmon species. Juvenile salmon encompass the alevin, parr, and smolt stages.

Figure 1.2 illustrates the range in the lighting spectrum; Figure 1.3 shows the color spectrum associated with visible light. Table 1.2 includes the most common light units reported in the literaturefoot-candles (ft-c) and lux — as well as examples of the amount of visual light these represent. Another unit of light, microeinsteins, is used to describe electromagnetic radiation and cannot be converted easily to lux without knowing the spectral distribution of the light source.

Table 1.1. Common and scientific names for Pacific Northwest salmon and trout used in light studies

\begin{tabular}{ll}
\hline \multicolumn{1}{c}{ Common Name } & \multicolumn{1}{c}{ Scientific Name } \\
\hline Chinook & Oncorhynchus tshawytscha \\
Sockeye/Kokanee & Oncorhynchus nerka \\
Steelhead/Rainbow trout & Oncorhynchus mykiss \\
Coho & Oncorhynchus kisutch \\
Chum & Oncorhynchus keta \\
Pink & Oncorhynchus gorbuscha \\
Cutthroat trout & Oncorhynchus clarkii \\
Brook char & Salvelinus fontinalis \\
\hline
\end{tabular}




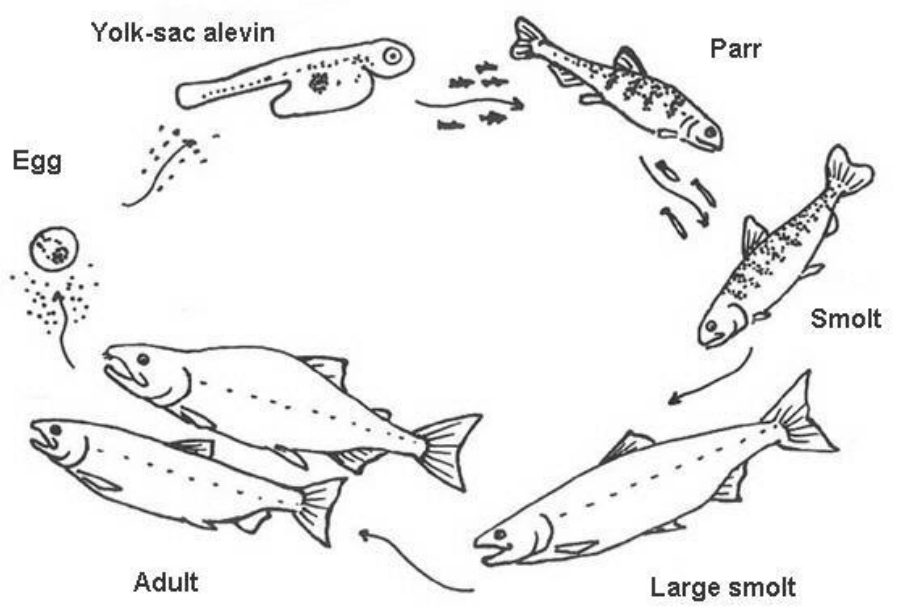

Figure 1.1. Life cycle of anadromous Pacific salmon showing major developmental stages. Illustration (C) Vancouver Aquarium Marine Science Centre (http://www.vanaqua.org/ salmontales/english); reproduced with permission.

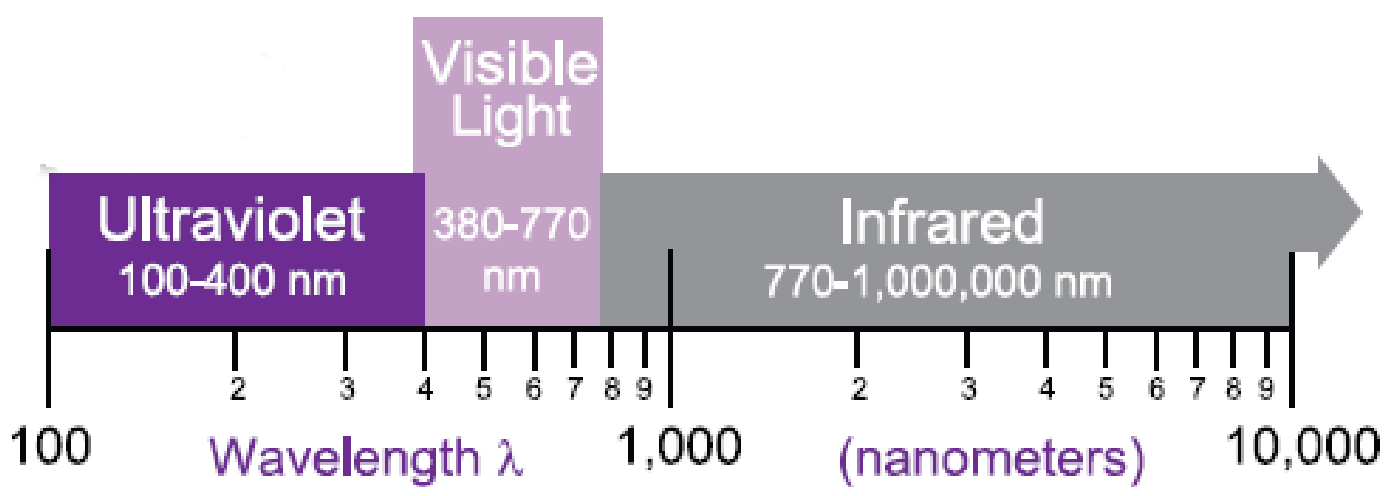

Figure 1.2. Entire light spectrum (from The Light Measurement Handbook, http://www.intl-light.com)

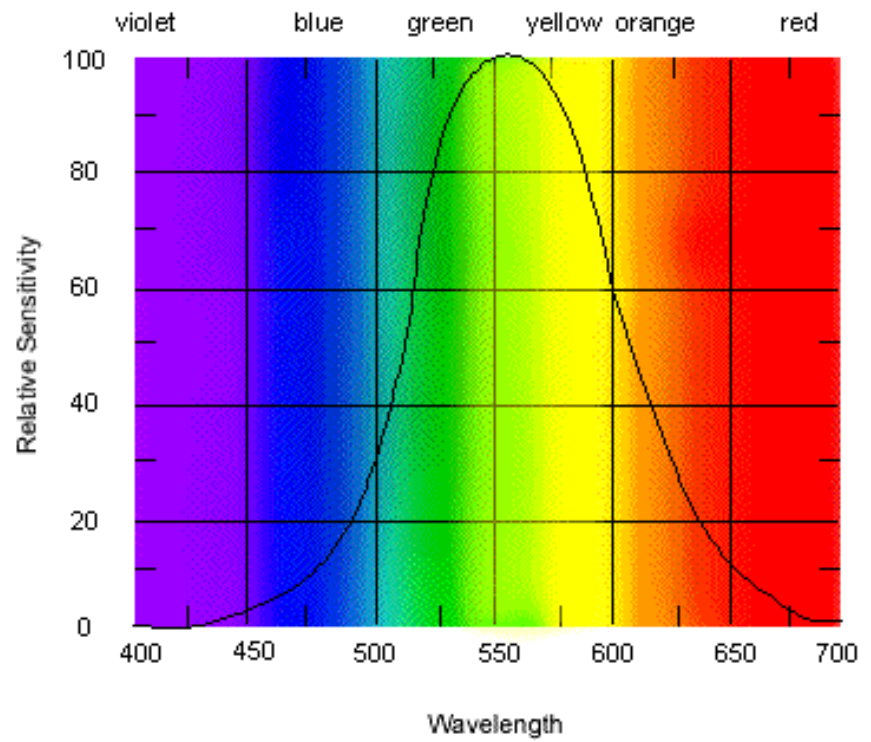

Figure 1.3. Visible color light spectrum and associated wavelengths (nanometers) 
Table 1.2. Light levels in lux and foot-candles for various levels of daylight (http://en.wikipedia.org/wiki/Daylight)

\begin{tabular}{lll}
\hline \multicolumn{1}{c}{ Example } & \multicolumn{1}{c}{ Lux } & \multicolumn{1}{c}{ Foot-Candles } \\
\hline Starlight & 0.00005 & $4.65 \mathrm{E}-06$ \\
Moonless overcast night sky & 0.0001 & $9.26 \mathrm{E}-06$ \\
Moonless clear night sky & 0.001 & 0.0000929 \\
Quarter moon & 0.01 & 0.000929 \\
Full moon on a clear night & 0.25 & 0.0232 \\
Moonlight & $<1$ & 0.0929 \\
Sunrise or sunset on a clear day & 400 & 37.2 \\
Sunlight on an average day (min) & 32,000 & 2973 \\
Sunlight on an average day (max) & 100,000 & 9290 \\
\hline Conversion: 1 foot-candle = 10.764 lux. & \\
\hline
\end{tabular}

The range of the visible light spectrum perceivable by the human eye encompasses wavelengths from 380 to 770 nanometers (nm). Many species of fish have visual sensitivities into the shorter wavelengths of the ultraviolet (UV) range starting at approximately $350 \mathrm{~nm}$ (Bowman et al. 1993) (Figure 1.4).

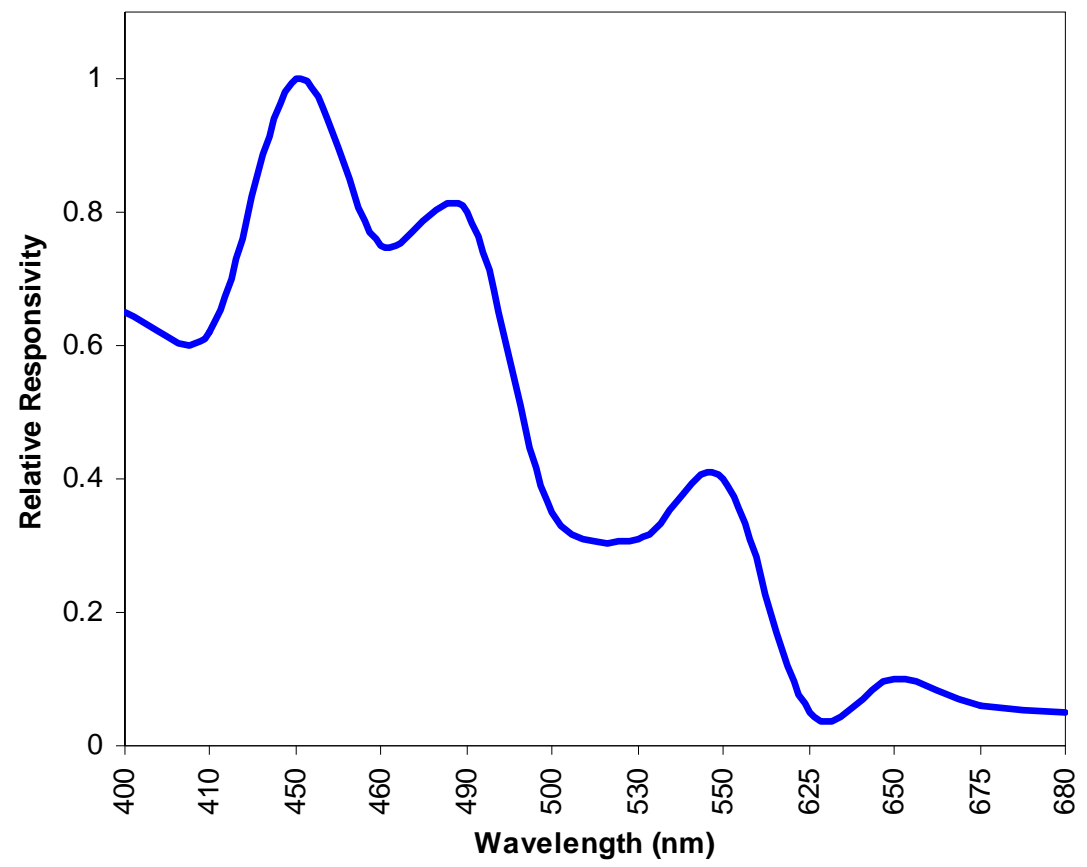

Figure 1.4. Average action spectra of six juvenile rainbow trout in a controlled laboratory experiment (Douglas 1983)

Our review first includes a discussion of behavior of juvenile salmonids with respect to ambient light levels, followed by a description of studies on the physiology of the fish's eye and the response to light stimulus. The next two sections of this chapter discuss results of laboratory and field studies of the response of fish to lights. 


\section{Juvenile Salmonid Fish Behavior}

The response of fish to light is dictated by a number of factors, including species, age, the light source, and previous exposure to light. Our main focus of this review was on anadromous Pacific salmonids that, after a varying amount of time in freshwater, migrate to the ocean and must pass around or through numerous dams. The collective physiological changes occurring as the salmon goes from freshwater to seawater are termed smoltification. Behaviorally, in preparation for downstream migration, the juvenile fish must leave in-shore or bottom habitats for the open water. Photoperiod has been linked to smoltification. The length of the photoperiod appears to influence plasma levels of thyroxine and cortisol, hematocrit levels, condition factor (length-weight relationship) and the hepatosomatic index (Hoffnagle and Fivizzani 1998). Both chum and coho salmon were found to prefer open water to shaded areas after exposure to elevated thyroid levels (Iwata 1995).

The behavioral response to light (both ambient and artificial) by juvenile salmonids varies with species and age. The alevins of Chinook salmon are initially negatively phototactic (Beauchamp et al. 1983) and migrate downward into the gravel. After yolk absorption, the fish emerge during nocturnal periods as free-swimming fry. Juvenile steelhead are primarily bottom feeders, occur in areas with the highest stream cover (Pauley et al. 1986), and tend to be quiescent at night (Simenstad et al. 1999). Sockeye fry are extremely light-sensitive and remain hidden under stones and debris during the day, emerging at dusk (Pauley et al. 1989). Pink and chum salmon show nocturnal activity and are either negatively phototaxic (Simenstad et al. 1999) or positively phototaxic (Hoar et al. 1957), depending on the light level. Juvenile coho salmon (74-104 mm) exhibit a strong cover-seeking reaction when exposed to full ambient daylight, while juvenile Chinook salmon (79-115 mm) appear unresponsive to light stimuli (Nemeth and Anderson 1992).

A multiyear monitoring study of juvenile fall Chinook salmon implanted with passive integrated transponder (PIT) tags migrating down the Snake River found shoreline collections of fish declined abruptly when the fish reached $60 \mathrm{~mm}$ fork length (Connor et al. 2003). Fish then moved offshore and began the downstream migration. A study at McNary Dam found that nearly $80 \%$ of migrating fall Chinook salmon smolts chose an uncovered channel versus a covered channel when presented with the choice (Kemp et al. 2005). These results provide additional evidence for a change in behavior associated with smoltification and subsequent downstream migration.

The diel movement and vertical distribution of migrating smolts of Chinook salmon, steelhead, and sockeye salmon at The Dalles and McNary dams on the Columbia River were evaluated in 1960 and 1961 (Long 1968). Results showed that more fish were caught at night compared to the numbers caught in the daytime. All catches were made at turbine intakes. In a study of residence time in the fish passage system at McNary Dam, most fish (juvenile Chinook salmon and steelhead) passed from the gatewell to the collection channel during the evening, regardless of the time they were released (i.e., midday vs. evening) (Beeman and Maule 2001). Evidence suggests that migration begins as light intensity falls below the cone threshold (Simenstad et al. 1999). At this light level, the fish is unable to maintain position in relation to a given reference point.

Schilt (2007) reviewed fish passage and protection at hydropower dams. In the Columbia River basin, he found juvenile salmon passage follows a diel trend, with deep passage through turbines and spill bays occurring in late evenings and early mornings, while shallow passage through surface routes occurs during daylight hours. He also noted that light-based behavioral guidance systems are limited by turbidity and habituation. 
Small fish avoid lights generally because of predation (Nemeth and Anderson 1992; Tabor et al. 2004). Tabor et al. (2004) in a series of laboratory and field experiments found downstream migration by sockeye fry was hindered by lights (maximum 10.8 lux), and the fish were then more vulnerable to predation by sculpin.

\section{Visual Systems}

Guiding fish through manmade structures using artificial lights requires an understanding of the types of illumination and the nature of salmonid light perception. For fish to respond to a light source, their visual system must be able to respond to the appropriate wavelengths that correspond to peaks in the spectral response of the photo receptors in the eye. Research suggests that the increase in the number of cones as the eye of juvenile fish grows larger leads to greater sensitivity and improved resolution of an image (Northmore et al. 1978; Fernald 1988). These developmental changes are important and provide for the ability to migrate at progressively lower light intensities. In addition, the spectral response of the eye differs within species and life stage of the fish (Fernald 1988). Studies that have examined the use of artificial light to guide salmonids safely through migration barriers such as hydroelectric dams show measurable differences in juvenile responses to both the quantity and quality of the light stimulus. Juvenile salmonids have specific sensitivity in the blue and green wavelengths; most freshwater teleosts have three cone pigments that absorb at their maximum around 455, 530, and $625 \mathrm{~nm}$ (Loew and Lythgoe 1978). The action spectra of juvenile rainbow trout peaks at approximately $450 \mathrm{~nm}$ (Figure 1.4).

The following studies examined the spectral sensitivity of Pacific salmon to visible and UV spectra. Several studies looked at species differences, and others investigated mortality related to light exposure.

The visual system of salmonids contains both rhodopsin and porphyropsin visual pigments (Alexander et al. 1994). Rhodopsin is associated with shorter wavelength spectral sensitivity, while porphyropsin is associated with longer wavelengths. Retina with equal mixtures of the two pigments will have intermediate spectral sensitivities. A study of coho salmon through the smoltification process found the proportion of these two visual pigments shifted from a porphyropsin-dominated visual pigment in presmolts to a rhodopsin-dominated retina in the smolt stage (Alexander et al. 1994). The shift in visual pigments was hypothesized to allow the fish better visual acuity in the marine environment, which allows for the passage of shorter wavelengths than do the freshwater habitats.

An extensive study of the structure of the eye in response to different light levels was conducted by Ali (1959). Four species of salmon (sockeye, chum, pink, and coho) were studied, from alevin through smolt stage. Physical changes in the eye as well as schooling and feeding behavior were evaluated. Figure 1.5 illustrates the results in relation to known light levels. In general, schooling and feeding occur at light levels occurring at dawn and dusk that correlate to intensities of $10^{-1}$ for coho salmon. Times for cones and pigment to fully adapt to light or dark conditions were between 10 and 20 minutes, depending on species and life stage. The times for cones to fully adapt correlated well with maximum feeding rates. The study concluded that downstream movement of juvenile salmonids occurs as a result of their eyes being in a semi-dark adapted state for a short duration at dusk. The fish gradually lose their reference points and swim with the current while being displaced downstream. 


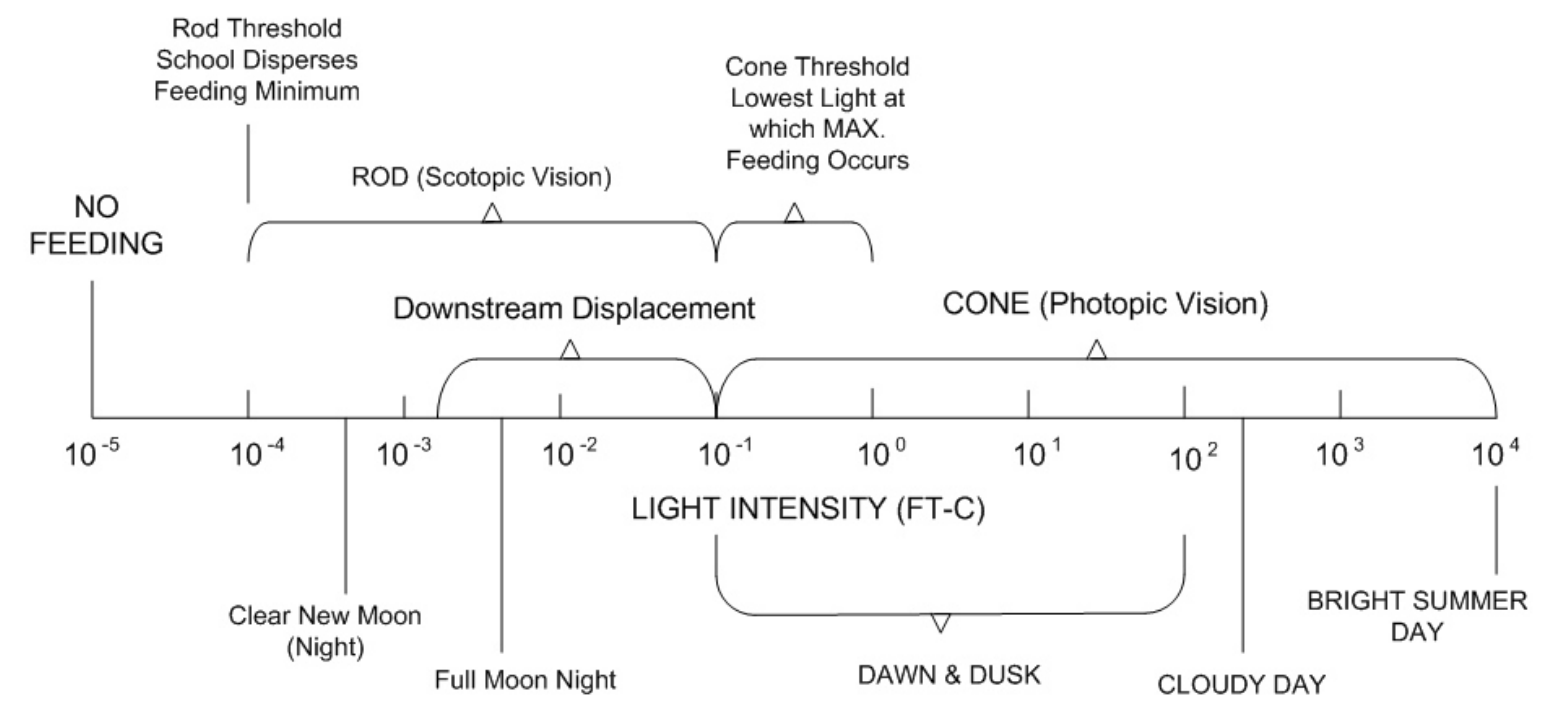

Figure 1.5. Response of juvenile Pacific salmon to various light intensities and the relationship to ambient light (Ali 1959, p. 987, Fig. 14; (C) Canadian Journal of Zoology; reproduced with permission)

A study of the photic environment of Lake Cowichan in British Columbia, Canada, found changes in both light intensity and spectral composition with depth and time of day (Novales-Flamarique et al. 1992). The spectral composition of surface layers had fairly equal proportions of UV, short, middle, and long wavelengths. Near the bottom, middle and long wavelengths dominated the spectra. Over the day, peaks in UV and blue light were noted prior to sunrise and immediately after sunset; the opposite occurred for long wavelengths. Similar changes in spectral composition may be evident also in large rivers such as the Columbia.

Parkyn and Hawryshyn (2000) found the spectral sensitivity in response to an increase in light differed among juvenile (parr) salmonid species. Specifically, the response was dominated by L- (long or red) and M- (medium or green) cone mechanisms in steelhead, rainbow, cutthroat trout, and brook char, while in kokanee the M-cone mechanism dominated. There were no species differences in the response to a decrease in light intensity. The differences noted for the light response may be linked to habitat; species with the L- and M-cone mechanisms inhabit streams and rivers, while kokanee is a lake species. Table 1.3 lists the maximum eye receptor cell response for rainbow trout, sockeye salmon, brown trout, and brook trout. 
Table 1.3. Comparison of the maximum spectral sensitivity of the photopic mechanisms in salmonids (from Bowmaker and Knuz 1987; Parkyn and Hawryshyn 2000)

\begin{tabular}{lc}
\hline \multicolumn{1}{c}{ Species } & Photopic Peak Cell Response (nm) \\
\hline Rainbow trout & $375,440,540,580$ \\
Sockeye salmon & $370,440,520,590$ \\
Brown trout & $355,441,535,600$ \\
Brook char & $370,420,540,560$ \\
\hline
\end{tabular}

Novales-Flamarique (2000) examined the spectral sensitivity of sockeye salmon throughout its life history. No differences were found in the cone mechanisms related to short-, middle - and longwavelength sensitivity over the life stages of these salmon. However, cones sensitive to UV wavelengths were found to disappear at the smolt stage and reappear in the adult. It was hypothesized that the UV cones improve prey contrast and that the loss of UV cones may be an accidental consequence of hormonal changes during smoltification. Similar results were noted for rainbow trout and steelhead (Deutschlander et al. 2001).

A test of foraging and prey-selection under polarized light by rainbow trout found prey were detected at greater distances under polarized light compared to unpolarized lights (Novales-Flamarique and Browman 2001). In another study, juvenile rainbow trout, steelhead, and brook trout were trained to orient relative to the axis of polarized light (Parkyn et al. 2003); however, untrained fish showed no orientation response.

The visual pigments and photoreceptor types in coho, chum, and Chinook salmon were examined relative to time of year and developmental stage (Novales-Flamarique 2005; Novales-Flamarique et al. 2006). All three species had visual pigments with maximum absorbance in the UV, blue, green, and red parts of the spectrum. However, fish in the alevin stage did not have blue visual pigments. All fish had rod photoreceptors with visual pigment in the 504- to 531-nm range. Temperature affected the peak absorption of the visual pigments during smoltification and appears to be linked to hormonal factors that vary with species, developmental stage, and environmental variables (Novales-Flamarique 2005).

One study looked at visual performance and physical changes in retinal morphology in sockeye and kokanee following exposure to strobe lights (Novales-Flamarique et al. 2006). Overall, there were no detectable changes after a 5-minute exposure to strobe lights; however, a 3-hour exposure resulted in mortality. Behaviorally, fish exposed to strobe lights showed an escape response to an overhead shadow.

In the review by Simenstad et al. (1999), the amount of time required for structural changes to occur in response to variations in light intensity varied with species and life stage. They report that 30 to 40 minutes were required for light-adapted chum and pink salmon to fully adapt to dark, while darkadapted fry required 20 to 25 minutes to adapt to increases in light. During these periods, visual acuity ranged from periods of blindness to slightly diminished, depending upon the magnitude of the contrast in light intensity.

In summary, it appears juvenile Pacific salmon are most sensitive to the blue-green spectra characteristic of mercury vapor lights. There were few species differences in visual morphology or spectral sensitivity. The major life-history change involves the loss of UV sensitivity during smoltification, which returns in adult fish. Overall, juvenile salmon are able to discern the wavelengths found in ambient light. 


\section{Laboratory Studies}

Early evaluations of the response of salmon species to light were conducted between 1959 and 1963 at the University of Washington (Fields 1966). The first tests were conducted in outdoor raceways using several species of young of the year salmon and steelhead. Tests conducted in both daytime and nighttime found fish preferred the darker side of the raceway. At night, fish avoided the artificially lighted side. In a separate study, juvenile salmon and steelhead (28 to $275 \mathrm{~mm}$ ) were placed in an aquarium and exposed to a light gradient. All species of downstream migrating salmon were found to prefer the darker portion of the light gradient. However, the fry of some species exposed previously to light (e.g., hatchery Chinook salmon) were attracted to the light.

In another series of tests, fish were exposed to multiple levels of light, water depth, and velocity (Fields 1966). The levels of illumination were 0.31 and $40 \mathrm{ft}-\mathrm{c}$ and water velocities of 0.37 and $3.90 \mathrm{ft} / \mathrm{sec}$. Results indicated that the fish generally avoided lighted areas, and fewer fish entered the lighted areas as the light intensity increased. However, velocity had a distinct effect on the response to light, with more fish found in lighted areas as the velocity increased. There was a species difference; steelhead were the most sensitive to light, and Chinook salmon the least.

Hoar et al. (1957) measured the attraction/avoidance response of several species of fry and smolt salmon (pink, coho, chum, and sockeye) to changing light levels. In the tests, fish had a choice of lighted or darkened areas within the aquarium. They were exposed to either increasing light levels (5 to $1000 \mathrm{ft}-\mathrm{c}$ ) or constant illumination (500 ft-c). The changes from one light level to the next were abrupt, and the fish remained at that level for 10 minutes before the light level was increased or decreased. Light levels used in the exposure were generally less than maximum sunlight; values given in the report indicate $1000 \mathrm{ft}-\mathrm{c}$ corresponds to light levels between 0900 and 1000 hours (Pacific Standard Time) in May in Fort St. John, British Columbia. In no case was the response all or none; fish would pass between the light and dark areas of the tanks. In general, the response to light was dependent on the species and age (fry vs. smolt) of the fish. Chum and pink salmon fry showed a preference for light, while sockeye fry retreated to darker areas and coho fry appeared to be indifferent to moderately high light levels and inactive at low light levels. The smolt stage of both sockeye and coho salmon was associated with an increasing sensitivity to light.

Puckett and Anderson (1988) conducted laboratory tests on juvenile Chinook salmon (average length $=53 \mathrm{~mm})$. The fish were exposed to an adaptation light $\left(0.1\right.$ to $\left.1 \mathrm{microeinstein} / \mathrm{m}^{2} / \mathrm{s}\right)$ for 20 minutes, then exposed to a stimulus light; behavior was monitored for 2 minutes. The intensity of the stimulus light varied such that the ratio of the stimulus light to the adaptation light ranged from 0.005 to 100. Water was flowing during the experiments, but no measure of velocity was given. The study found that juvenile Chinook salmon were attracted to light, and the strength of the attraction was related to the ratio of intensity of stimulus to adaptation light. Maximum attraction was when the ratio was 1 and light levels were $0.5 \mathrm{microeinstein} / \mathrm{m}^{2} / \mathrm{s}$ (which approximates moonlight). Attraction was less as either the stimulus light increased relative to the adaptation light or decreased relative to the adaptation light. Puckett and Anderson noted that when the stimulus light was brighter than the adaptation light, fish were attracted to the dim zone that bounded the intense light spot. When the ratio was 100, fish were observed to swim to the farthest reaches of the test flume. 
The behavioral response of juvenile coho and Chinook salmon to mercury lights was evaluated under different pre-exposure light regimes (Nemeth and Anderson 1992). In these tests, fish were adapted to one of four conditions: normal daylight, normal nighttime, and reversed day and reversed night. For reversed day, the test raceway was darkened during the day, while for reversed night, the raceway was illuminated at night. Fish were then exposed for an hour to a mercury vapor light. Light intensity in the raceway varied from 100 microeinsteins $/ \mathrm{m}^{2} / \mathrm{s}$ at $1 \mathrm{~m}$ to near zero at $8 \mathrm{~m}$; the raceway was $8.8 \mathrm{~m}$ long. Under ambient light adaptation, coho salmon hid during the day and swam actively at night when exposed to mercury lights. Under reversed adaptation, there was no clear response; approximately half of the fish were passive, while the other half were active (dark adapted during the day) or hiding (light adapted during the night). For Chinook salmon, there was no response to lights during the day under ambient lighting, while at night fish first actively swam toward the lights and then away. Under reversed adaptation, Chinook salmon swam actively when the mercury light was turned on. Mercury vapor lights emit in the blue-green range (450-550 nm) (Pauley et al. 1986).

A floating test platform in the Yakima River was used to evaluate the response of Chinook salmon smolts to drop lights (Amaral et al. 2001). The movement of fish with respect to the lights was videotaped under ambient daylight and dusk conditions. At night, additional low-level lights were used to facilitate the video recording. Test conditions involved 1- and 2-minute exposures to lights, separated by a rest period. In addition, the lights were either on continuously during the test or turned on/off every 1 or 15 seconds. Results indicated a weak avoidance, with fish generally moving less than $0.5 \mathrm{~m}$ further from the lights when they were on. The authors mentioned there was no startle response and only a few dramatic movements in response to the lights.

Kelly and Bothwell (2002) examined the response of juvenile coho salmon to UV radiation. In the experiments, an outdoor test enclosure was covered with two solar exclusion panels, creating a binary choice for the fish. The panels contained filters that allowed fish to be exposed to only photosynthetically active radiation (PAR; 400-700 nm), PAR plus UV-A (320-400 nm), PAR plus UV-A and UV-B (280-320 nm), and 50\% PAR plus UV-A and UV-B. Results showed fish had a significant preference for the absence of UV radiation. This preference was not evident on cloudy days when solar intensity was half that under full summer sun. The avoidance of high light environments by juvenile salmonids has been linked to a predator avoidance response, but it also could be an avoidance of harmful UV radiation.

An experiment evaluating fish (smolts of coho, Chinook, and steelhead) response to a bypass system found that $70 \%$ to $90 \%$ of the fish preferred the side of the model constructed of clear Plexiglas (Wert 1988). When the Plexiglas was covered with opaque plastic, fish appeared to swim randomly within the model.

A laboratory test of juvenile salmonid response to strobe lights found that, after an initial escape response, fish were observed to maintain position or follow the penumbra (i.e., the edge between darkness and intense brightness of the strobe light) (Hays 1988). No light levels were given.

Douglas (1983) conducted laboratory tests on the corneas of rainbow trout that were exposed to 150-W tungsten light and a monochromatic light. He found the light output of the tungsten white light served as a broad-based band stimulus and tended to stimulate all types of visual receptors in juvenile rainbow trout. This study also showed that rainbow trout have the ability to distinguish color. 


\section{Field Studies}

The University of Washington conducted field studies in addition to its laboratory work (Finger and Fields 1957; Fields et al. 1958; Fields 1966). These studies focused on using lights to guide fish downstream. In Minter Creek, a light barrier was tested and found to stop a large part of the downstream migration. In this situation, the lights repelled the fish; however, if the fish were exposed to lights in lowvelocity areas $(0.5 \mathrm{ft} / \mathrm{s})$, then fish were attracted to the lights, albeit dim $(0.015 \mathrm{ft}-\mathrm{c})$. Tests at White River bypass again found fish avoided lights; the degree of avoidance was dependent on the turbidity. However, fish were attracted to a dim light $(<0.015 \mathrm{ft}-\mathrm{c})$ in both clear and turbid conditions. Also, light attraction was obtained if fish were allowed to adapt to the barrier lights in low-velocity areas.

The remaining studies conducted by the University of Washington (Fields 1966) were at the McNary and The Dalles dams. Most of the fish were Chinook salmon fry and smolts. Results from McNary Dam point to an interaction between three factors: flow velocity, light adaptation, and light intensity. In 1959, fish avoided a 200-W lamp placed in front of an intake structure. In 1963, fish appeared to not respond to the light (with either attraction or repulsion). The main difference between the two years was flow, with discharge in 1959 at $1150 \mathrm{cfs}$, while in 1963, discharge was $650 \mathrm{cfs}$. Fields indicates that avoidance of lights was associated with high velocities. He postulated that the fish's retina does not adapt fast enough at higher velocities, and the primary response is avoidance.

A study conducted at McNary Dam in 1969 (Marquette et al. 1970) evaluated the effect of light on passage of wild or naturally migrating coho, sockeye, and Chinook salmon, and steelhead trout smolts from gatewells through orifices into the collection channel. The effect of illumination was evaluated at both the gatewell and orifice; the gatewells were either covered or uncovered, while test conditions near the orifices included ambient lighting, electrical lights (150-W halogen flood lamp), and total darkness. The testing period ranged from 24 to 48 hours. For the 24-hour tests, the lowest retention in the gatewell - 3\% for sockeye, $7 \%$ for steelhead trout, $14 \%$ for coho, and 26\% for Chinook salmon-was seen when the gatewell was dark and the orifice was lighted. For longer-term tests (36-48 hours) (all with a darkened gatewell), Chinook salmon showed a preference for a lighted orifice ( $75 \%$ passage rate) while steelhead trout and sockeye salmon showed no preference for the light condition at the orifice. The study recommended that all orifices be illuminated continuously with electric lights to help fish locate and pass through these structures.

Brett and MacKinnon (1953) tested the response of juvenile spring migrating salmon to a bubble curtain and lights in a canal that connected the Puntedge River in British Columbia to a powerhouse. The lights were three sealed-beam headlights that were either continuously on or flashing at a rate on 1/sec. Light intensity at the water surface was $3.5 \mathrm{ft}-\mathrm{c}$. All experiments were conducted at night. Results indicated lights, either flashing or continuous, were effective in diverting approximately two-thirds of the fish from one side of the canal to the other.

Congleton and Wagner (1988) evaluated the stress response (i.e., plasma cortisol levels) in relation to light intensity (and flume design) for migrating smolts of Chinook salmon and steelhead. At night, plasma cortisol levels were higher for both species after passing through the flumes. During the day, Chinook salmon smolts passing though the darkened flumes had the lowest cortisol levels, lower even than the baseline. The highest plasma cortisol levels were associated with Chinook salmon going through uncovered corrugated flumes during the day. For steelhead tested during the day, plasma cortisol levels 
generally increased for fish passing through the flumes, regardless of the light levels in the flumes. The light levels during holding prior to testing were not given.

Studies at Wanapum Dam in 1989 tested the effectiveness of mercury lights to improve the passage of juvenile salmonids. The lights were installed on the pier noses and spillway gates to a depth of 3 to $6 \mathrm{~m}$ during the nighttime period and monitored with hydroacoustics. The study found no statistical differences in fish passage rates with the lights on or off. The authors suggest the results should be considered inconclusive, based on the short duration and limited illuminated region (Coutant 2001).

\section{Discussion}

Rainey (1985) reviewed various design features of juvenile bypass systems including light. He references Fields' results (1966) and concludes that avoidance by juvenile fish is based on visual response, touch, or perception of a change in hydraulic condition. Juvenile salmonids normally face upstream during outmigration, and most migration occurs at night (2000 to 2400 hours).

While the studies indicate a variable response to light, the most compelling studies by Hoar et al. (1957), Fields (1966), and Puckett and Anderson (1988) indicate the variability in response is probably due to light acclimation and the intensity of the light. Generally, fish appear to avoid or be startled by sudden exposure to intense light levels. Even studies that examined fish response to flows found fish attracted to lighted areas (Wert 1988).

Results of behavioral studies of the response to juvenile salmonids to light (non-strobe) range from no effect to attraction. As Hoar et al. (1957) noted, the response to moderate light intensities (i.e., less than full daylight) was never complete attraction or repulsion. Fish swam in and out of the light and, depending on species, age, and number of fish present, spent more or less time in the light.

Finally, Schilt (2007) indicates that “...with all behavioral methods it is important to be aware that the visual system and hearing and all of the other systems operate in concert within themselves and among each other and responses to a sound might be affected by light level, current, or any number of other sensory factors." The following factors have been identified as enhancing or limiting the response to stimuli: genetic makeup (species and subspecies), life stage, season, time of day, light levels, presence of predators, distance to cover, temperature, group size, noise regime, and current. He cautions that the development of an effective juvenile fish passage system must be based on an understanding of fish behavior.

\section{References}

Alexander G, R Sweeting, and B McKeown. 1994. The shift in visual pigment dominance in the retinae of juvenile coho salmon (Oncorhynchus kisutch): an indicator of smolt status. Journal of Experimental Biology 195:185-197.

Ali MA. 1959. The ocular structure, retinomotor and photo-behavioral responses of juvenile Pacific salmon. Canadian Journal of Zoology 37:965-996. 
Amaral SV, FC Winchell, and TN Pearsons. 2001. Reaction of Chinook salmon, northern pikeminnow, and smallmouth bass to behavioral guidance stimuli. American Fisheries Society Symposium 26:125-144.

Beauchamp DA, MF Shepard, and GB Pauley. 1983. Species Profiles: Life Histories and Environmental Requirements of Coastal Fishes and Invertebrates (Pacific Northwest): Chinook Salmon. Biological Report FWS/OBS-82/11.6, U.S. Fish and Wildlife Service, National Wetlands Research Center, Lafayette, Louisiana.

Beeman JW and AG Maule. 2001. Residence times and diel passage distributions of radio-tagged juvenile spring Chinook salmon and steelhead in a gatewell and fish collection channel of a Columbia River dam. North American Journal of Fisheries Management 21:455-463.

Bowmaker JK and YW Kunz. 1987. Ultraviolet receptors, tetrachromatic colour vision and retinal mosaics in the brown trout (Salmo trutta): age dependent changes. Vision Research 27:2101-2108.

Brett JR and D MacKinnon. 1953. Preliminary experiments using lights and bubbles to deflect migrating young spring salmon. Journal Fisheries Research Board of Canada 10(8):548-559.

Browman HI, I Novales-Flamarique, and CW Hawryshyn. 1993. Ultraviolet photoreception contributes to prey search behavior in two species of zooplanktivorous fishes. Journal of Experimental Biology 186:187-198.

Congleton JL and EJ Wagner. 1988. Effects of light intensity on plasma cortisol concentrations in migrating smolts of Chinook salmon and steelhead held in tanks or raceways and after passage through experimental flumes. Transactions of the American Fisheries Society 117:385-393.

Connor WP, RK Steinhorst, and HL Burge. 2003. Migrating behavior and seaward movement of wild subyearling fall Chinook salmon in the Snake River. North American Journal of Fisheries Management 23:414-430.

Coutant CC (ed). 2001. Behavioral Technologies for Fish Passage Guidance. Symposium 26, American Fisheries Society, Bethesda, Maryland.

Deutschlander ME, DK Greaves, TJ Haimberger, and CW Hawryshyn. 2001. Functional mapping of ultraviolet photosensitivity during metamorphic transitions in a salmonid fish, Onchorhynchus mykiss. Journal of Experimental Biology 204:2401-2412.

Douglas RH. 1983. Spectral sensitivity of rainbow trout (Salmo gairdneri). Revue Canadienne de Biologie Experiméntale 42:117-122.

Fernald RD. 1988. Aquatic adaptations in fish eyes. In Sensory Biology of Aquatic Animals, J Atema, RR Fay, AN Popper, and WN Tavolga (eds), pp. 435-466. Springer-Verlag, New York.

Fields PE. 1966. Final Report on Migrant Salmon Light Guiding Studies at Columbia River Dams. Report to U.S. Army Corp of Engineers, Portland, Oregon. 
Fields PE, AK Murray, DE Johnson, and GL Finger. 1958. Guiding Migrant Salmon by Light Repulsion and Attraction in Fast and Turbid Water. Technical Report No. 36 and 41, College of Fisheries, University of Washington, Seattle.

Finger GL and PE Fields. 1957. The Role of Light Adaptation on Negative Phototaxis in Silver Salmon (Oncorhynchus kisutch). Technical Report No. 34, School of Fisheries, University of Washington, Seattle.

Hays SG. 1988. Low fish guidance with a turbine intake submersible traveling screen due to avoidance behavior: a case study. In Proceedings: Fish Protection at Steam and Hydroelectric Power Plants, WC Micheletti (ed). Electric Power Research Institute, Palo Alto, California.

Hoar WS, MHA Keenleyside, and RG Goodall. 1957. Reactions of juvenile Pacific salmon to light. Journal of the Fisheries Research Board of Canada 14:815-830.

Hoffnagle TL and AJ Fivizzani, Jr. 1998. Effect of three hatchery lighting schemes on indices of smoltification in Chinook salmon. The Progressive Fish Culturist 60:179-191.

Iwata M. 1995. Downstream migratory behavior of salmonids and its relationship with cortisol and thyroid hormones: a review. Aquaculture 135:131-139.

Kelly DJ and ML Bothwell. 2002. Avoidance of solar ultraviolet radiation by juvenile coho salmon (Oncorhynchus kisutch). Canadian Journal of Fisheries and Aquatic Sciences 59:474-482.

Kemp PS, MH Gessel, and JG Williams. 2005. Seaward migrating subyearling Chinook salmon avoid overhead cover. Journal of Fish Biology 67:1381-1391.

Long CW. 1968. Diel movement and vertical distribution of juvenile anadromous fish in turbine intakes. Fishery Bulletin 66:599-609.

Loew ER and JN Lythgoe. 1978. The ecology of cone pigments in teleost fish. Vision Research 18:715-722.

Marquette W, F Ossiander, R Duncan, C Long, and RF Krcma. 1970. Research on Gatewell-Sluice Method of Bypassing Downstream Migrant Fish Around Low-Head Dams. Final Report, Biological Laboratory, Bureau of Commercial Fisheries, Seattle, Washington.

Nemeth RS and JJ Anderson. 1992. Response of juvenile coho and Chinook salmon to strobe and mercury vapor lights. North American Journal of Fisheries Management 12:684-692.

Northmore DPM, FC Volkmann, and D Yager. 1978. Vision in fishes: color and pattern. In The Behavior of Fish and Other Aquatic Animals, D. Mostofsky (ed). Academic Press, New York.

Novales-Flamarique I. 2000. The ontogeny of ultraviolet sensitivity, cone disappearance and regeneration in the sockeye salmon, Oncorhynchus nerka. Journal of Experimental Biology 203:1161-1172. 
Novales-Flamarique I. 2005. Temporal shifts in visual pigment absorbance in the retina of Pacific salmon. Journal of Comparative Physiology A 191:37-49.

Novales-Flamarique I and HI Browman. 2001. Foraging and prey-search behavior of small juvenile rainbow trout (Orcorhynchus mykiss) under polarized light. Journal of Experimental Biology 204:2415-2422.

Novales-Flamarique I, A Hendry, and CW Hawryshyn. 1992. The photic environment of a salmon nursery lake. Journal of Experimental Biology 169:121-141.

Novales-Flamarique I, S Hiebert, and J Sechrist. 2006. Visual performance and ocular system structure of kokanee and sockeye salmon following strobe light exposure. North American Journal of Fisheries Management 26:453-459.

Parkyn DC and CW Hawryshyn. 2000. Spectral and ultraviolet-polarization sensitivity in juvenile salmonids: a comparative analysis using electrophysiology. Journal of Experimental Biology 203:1173-1191.

Parkyn DC, JD Austin, and CW Hawryshyn. 2003. acquisition of polarized-light orientation in salmonids under laboratory conditions. Animal Behavior 65:893-904.

Pauley GB, BM Bortz, and MF Shepard. 1986. Species Profiles: Life Histories and Environmental Requirements of Coastal Fishes and Invertebrates (Pacific Northwest): Steelhead Trout. Biological Report 82(11.62), U.S. Fish and Wildlife Service, National Wetlands Research Center, Lafayette, Louisiana.

Pauley GB, R Risher, and GL Thomas. 1989. Species Profiles: Life Histories and Environmental Requirements of Coastal Fishes and Invertebrates (Pacific Northwest): Sockeye Salmon. Biological Report 82(11.116), U.S. Fish and Wildlife Service, National Wetlands Research Center, Lafayette, Louisiana.

Puckett KJ and JJ Anderson. 1988. Conditions under which lights attracts juvenile salmon. In Proceedings: Fish Protection at Steam and Hydroelectric Power Plants, WC Micheletti (ed). Electric Power Research Institute, Palo Alto, California.

Rainey WS. 1985. Considerations in the design of juvenile bypass systems. In Proceedings of the Symposium on Hydropower and Fisheries, FW Olson, RG White, and RH Hamre (eds). American Fisheries Society, Bethesda, Maryland.

Schilt CP. 2007. Developing fish passage and protection at hydropower dams. Applied Animal Behavior Science 104:295-325.

Simenstad CA, BJ Nightingale, RM Thom, and DK Shreffler. 1999. Impacts of Ferry Terminals on Juvenile Salmon Migrating Along Puget Sound Shorelines Phase I: Synthesis of State of Knowledge. Washington State Transportation Center, University of Washington, Seattle. 
Tabor RA, GS Brown, and VT Luiting. 2004. The effect of light intensity on sockeye salmon fry migratory behavior and predation by cottids in the Cedar River, Washington. North American Journal of Fisheries Management 24:128-145.

Wert M. 1988. Hydraulic model evaluation of the Eicher passive pressure screen fish bypass system. In Proceedings: Fish Protection at Steam and Hydroelectric Power Plants, WC Micheletti (ed). Electric Power Research Institute, Palo Alto, California. 


\title{
Chapter 2
}

\section{Field and Laboratory Tests of Lights and Light Intensities with Reference to Use in Gatewell Orifice Structures at the Bonneville Dam Second Powerhouse}

\author{
Robert P. Mueller
}

\section{Background}

The U.S. Army Corps of Engineers (USACE) has been using lighting associated with the orifice locations at all Columbia and Snake River projects. The basic location and lighting used varies from project to project, and no studies have been conducted to characterize the lighting environment or determine if the lighting systems are effective at improving fish passage. During the 2007 fish passage season, the halogen lights along the Bonneville Dam second powerhouse (B2) were replaced with lightemitting diodes (LEDs) for cost savings, lower heat output, and longer bulb life. A total of two lights are used per orifice opening. Units 15 through 18 have one orifice each, while units 11 through 14 have two orifices for each gatewell. The lights are easily accessed within the downstream migration (DSM) channel. The lights are operated 24 hours/day during the entire fish passage season (April 1-December 15). During the year, project biologists observed that the new lights had a much lower intensity and expressed concern that the lower intensity and the green hue produced by the lights may not be providing adequate light stimulus for fish in the gatewell to move to the regions where they could then be passed downstream via the smolt bypass system.

As downstream migrating fish encounter hydropower projects, they are initially screened from turbines and guided upward into the gatewell near the forebay (Figure 2.1). The objective of the initial phase of the fish collection and bypass system is to safely guide migrants via intake screen to swim into the gatewells and then exit into the collection channel via underwater orifices. The orifices are located near the upper portion of the water column and near the corners of each gatewell. Early work by K. L. Liscom, Bureau of Commercial Fisheries, ${ }^{\text {(a) }}$ showed that more fish would enter the orifices at these locations. Once fish enter the gatewell, it is important that they do not reside in these areas for extended periods. Studies have shown that excess residency in this area can result in a variety of stresses, including those from delay and crowding (particularly in gatewells equipped with standard-length submersible traveling screens) and excessive descaling and injury (in gatewells equipped with extended-length submersible bar screens [Ferguson et al. 2005]). Assessments of orifice passage efficiency (OPE) have been conducted at several USACE projects using fin-clipped or PIT-tagged fish, with the percentage of fish leaving the gatewell in 24 hours constituting the OPE.

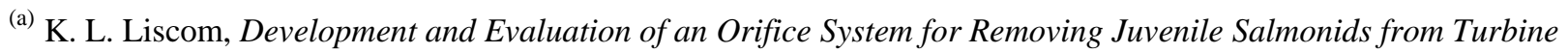
Intake Gatewells. 1966 unpublished report, Fish Passage Research Program, Bureau of Commercial Fisheries, Seattle. Washington. 
The regionally accepted minimum level for OPE with submersible traveling screens installed is $70 \%$. However, because of the increased flows and higher turbulence in gatewells associated with extendedlength bar screens, OPE levels approaching $90 \%$ are probably more appropriate for gatewells with these guidance devices (Ferguson et al. 2005). Studies at the B2 in 2001 using PIT-tagged fish showed an OPE of $94 \%$ to $97 \%$ for yearling Chinook salmon and near 100\% for subyearling Chinook salmon (Monk et al. 2002).

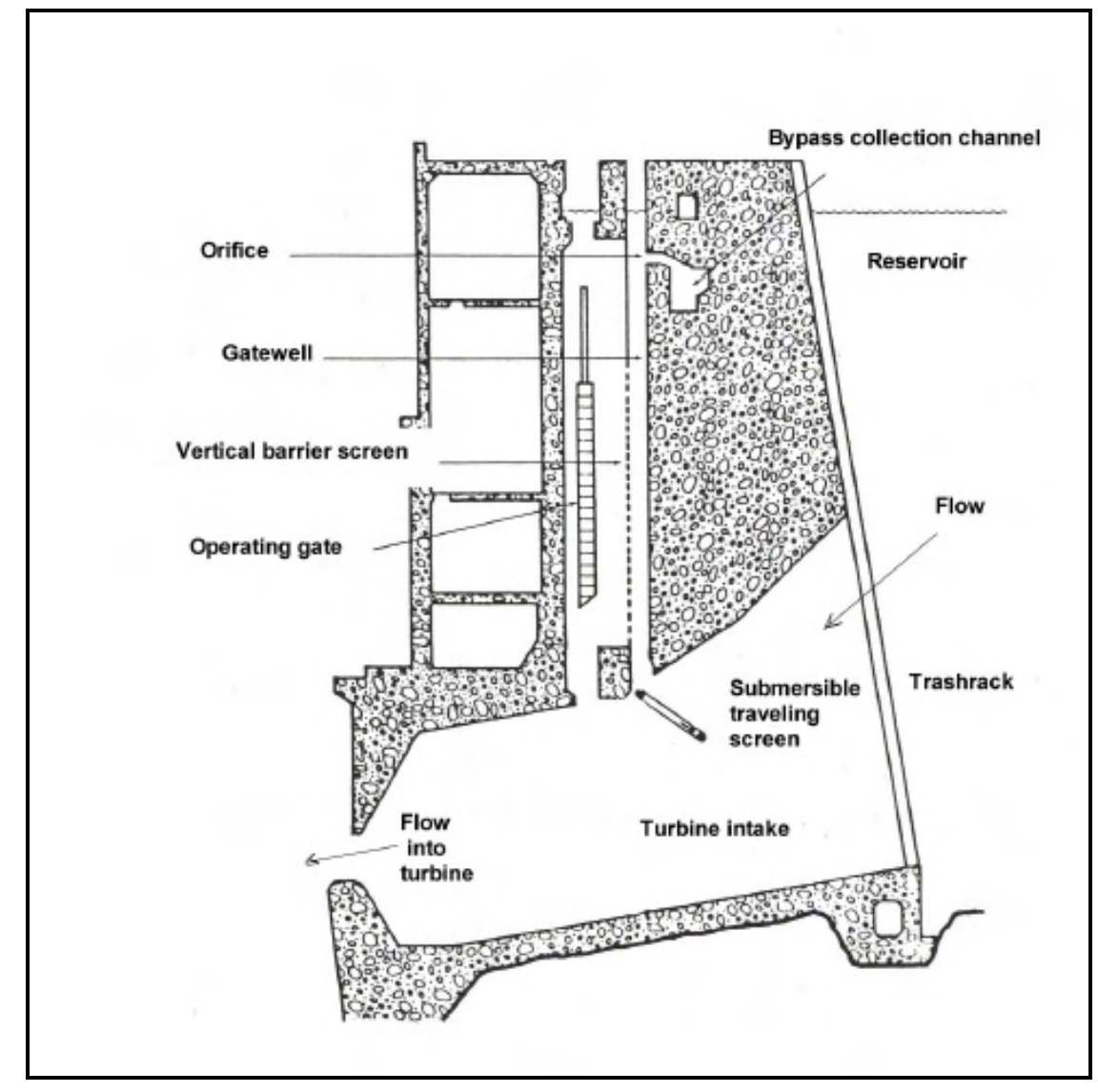

Figure 2.1. Cross section of a typical Columbia River hydroelectric project illustrating the mechanical bypass system

\section{Methods}

\section{Field Study}

Field measurements were made on October 31 and November 1, 2007, at the B2 in Gatewell 12A at the south orifice. A custom-made trolley was lowered to the orifice opening via a rope and pulley system attached to a framework that spanned the gatewell opening at the road deck. The trolley apparatus was constructed from 1-in.-square aluminum tubing approximately $3 \mathrm{ft}$ by $7 \mathrm{ft}$, with 2-in.-diameter caster wheels attached at each end and 5-lb lead weights at the corners to facilitate submergence (Figure 2.2). An underwater camera with incorporated LED lights also was attached to the light sensor to verify the sensor location at the orifice opening. All measurements were made during the daylight hours, with the 
top of the gatewell completely covered with canvas and plastic tarpaulins to eliminate ambient light and simulate nighttime conditions. The orifice gate at the terminus of the orifice opening was closed during the light measurements. The water turbidity was measured in nephlometric turbidity units (NTU) with a LaMotte Model 2008 portable turbidimeter.

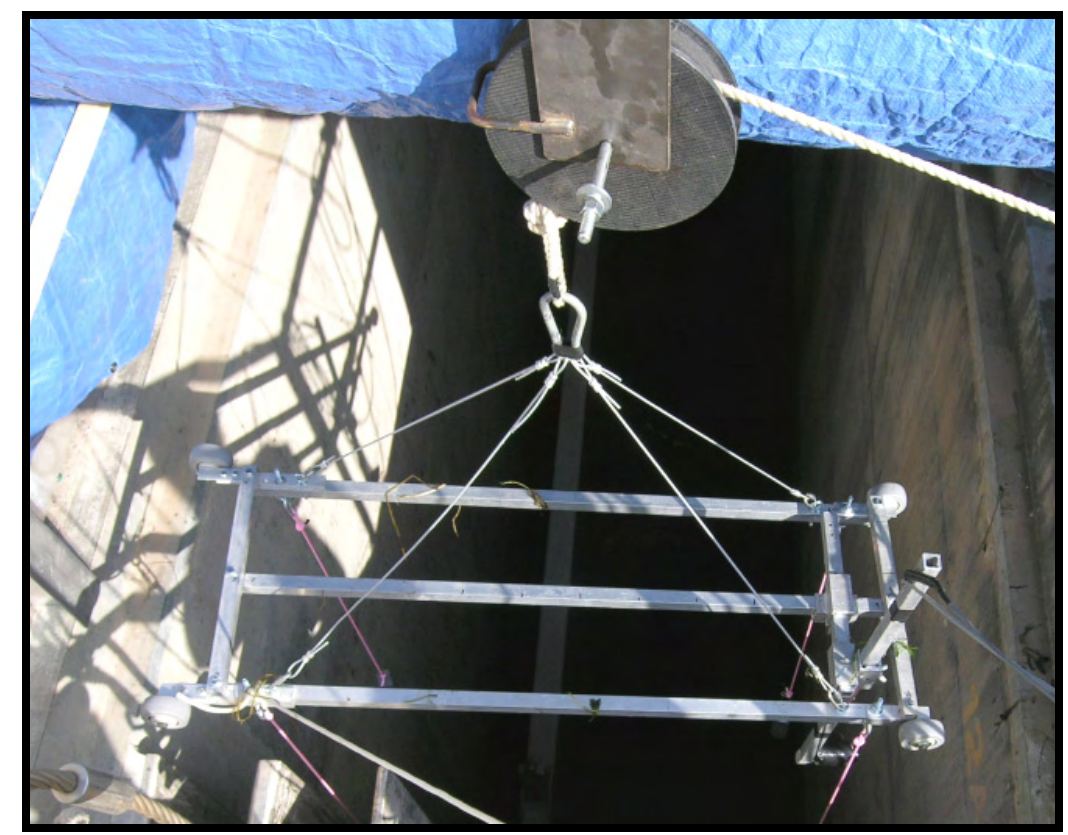

Figure 2.2. Support frame and weighted trolley used to deploy light sensor in Gatewell 12A

Four separate lighting conditions were evaluated. For conditions 1 and 2, the existing LED spot lamps were tested with the water-scaled and new (clean) lens caps, respectively. For conditions 3 and 4, 90-W halogen flood lights in the DSM channel were evaluated with the dirty and clean lens caps. All lamps were placed in a light receptacle with a heat shield and placed 1 to 2 in. from the lens cap (Figure 2.3).

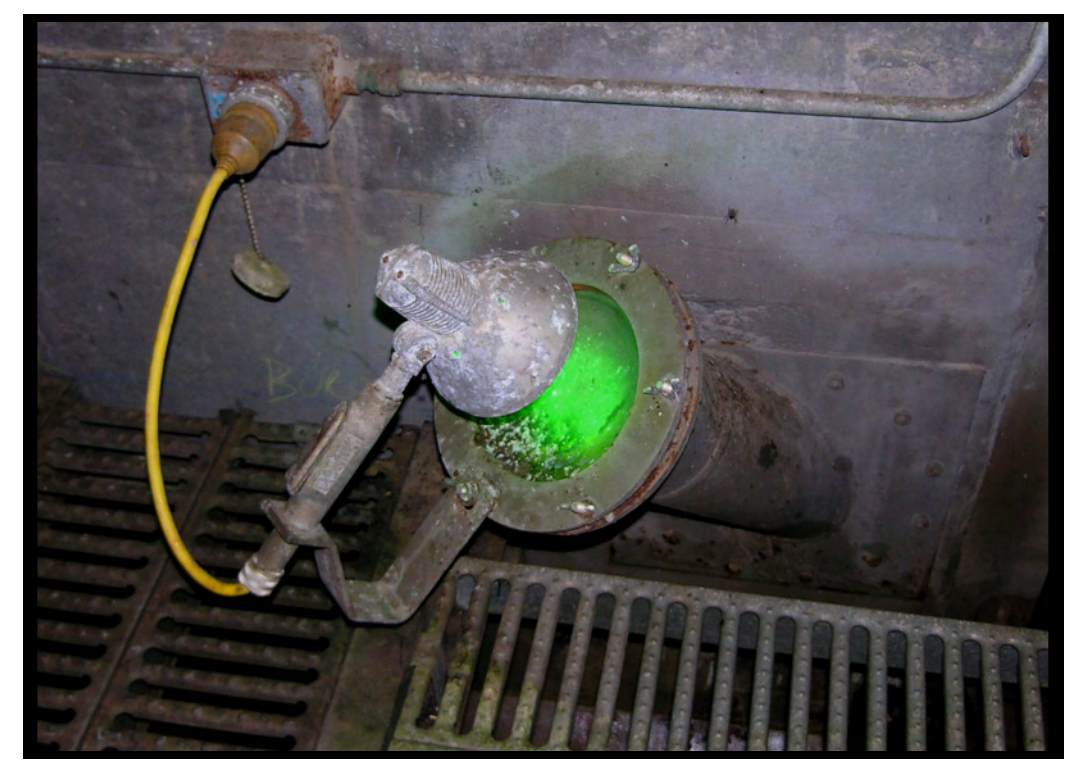

Figure 2.3. Light-emitting diode light installed above light tube at Orifice 12A South 


\section{Light Sensor}

A calibrated underwater high-gain luminance detector (International Light [IL] Model SHD033) was used along with an IL Model 1700 research radiometer/photometer. This sensor has a broad spatial response and is capable of detecting very low light levels. The sensor has a spectral range of 470 to $700 \mathrm{~nm}$, with peak sensitivity at $555 \mathrm{~nm}$. The light detector outputs the average light intensity in lux units. The sensor was mounted to the trolley frame and could be repositioned easily using a locking slide sleeve fastened to 1-in.square aluminum tubing (Figure 2.4). Calibration marks were made on the framework to replicate sensor position for each series of measurements.

\section{Light Types}

Two light sources were tested in the field and in the laboratory. The LED lamps currently in use at the B2 collection channel are manufactured by LEDtronics, Inc. (Model R30). The lights used previously were a standard 90-W Phillips halogen PAR flood lamp. A typical halogen light spectrum peaks in the range of 650 to $950 \mathrm{~nm}$ (Figure 2.5). One LED flood lamp is installed for each orifice tube. The specifications for each of these light sources are listed in Table 2.1.

\section{Orifice Layout}

The B2 consists of eight turbine units, each with three screened gatewells open at the top and measuring $4.1 \mathrm{ft}$ wide by $23 \mathrm{ft}$ long by approximately $50 \mathrm{ft}$ deep (water depth). The water elevation within the gatewell was at about $75 \mathrm{ft}$ above mean sea level. There are two orifices in each gatewell at an elevation of $65 \mathrm{ft}$ mean sea level, each measuring $12.5 \mathrm{in}$. in diameter (Figure 2.6). The south orifice is 36 in. from the end wall; the north orifice is centered at $16 \mathrm{in}$. from the end wall. The orifice extends 30 in. and terminates in the dewatering channel in the DSM channel at an elevation of $67 \mathrm{ft}$ mean sea level. Each orifice has two light tubes, approximately 7 in. in diameter and 54 in. long, which are angled upward and terminate in the DSM channel (Figure 2.7). Each light tube has a glass lens that seals the upper end of the light tube. The exposed portion of the lens cap is subjected to the wet and damp environment of the DSM channel. This environment, in combination with the heat produced by the halogen light, causes water scale and debris buildup on the lens, greatly diminishing the clarity of the glass. 


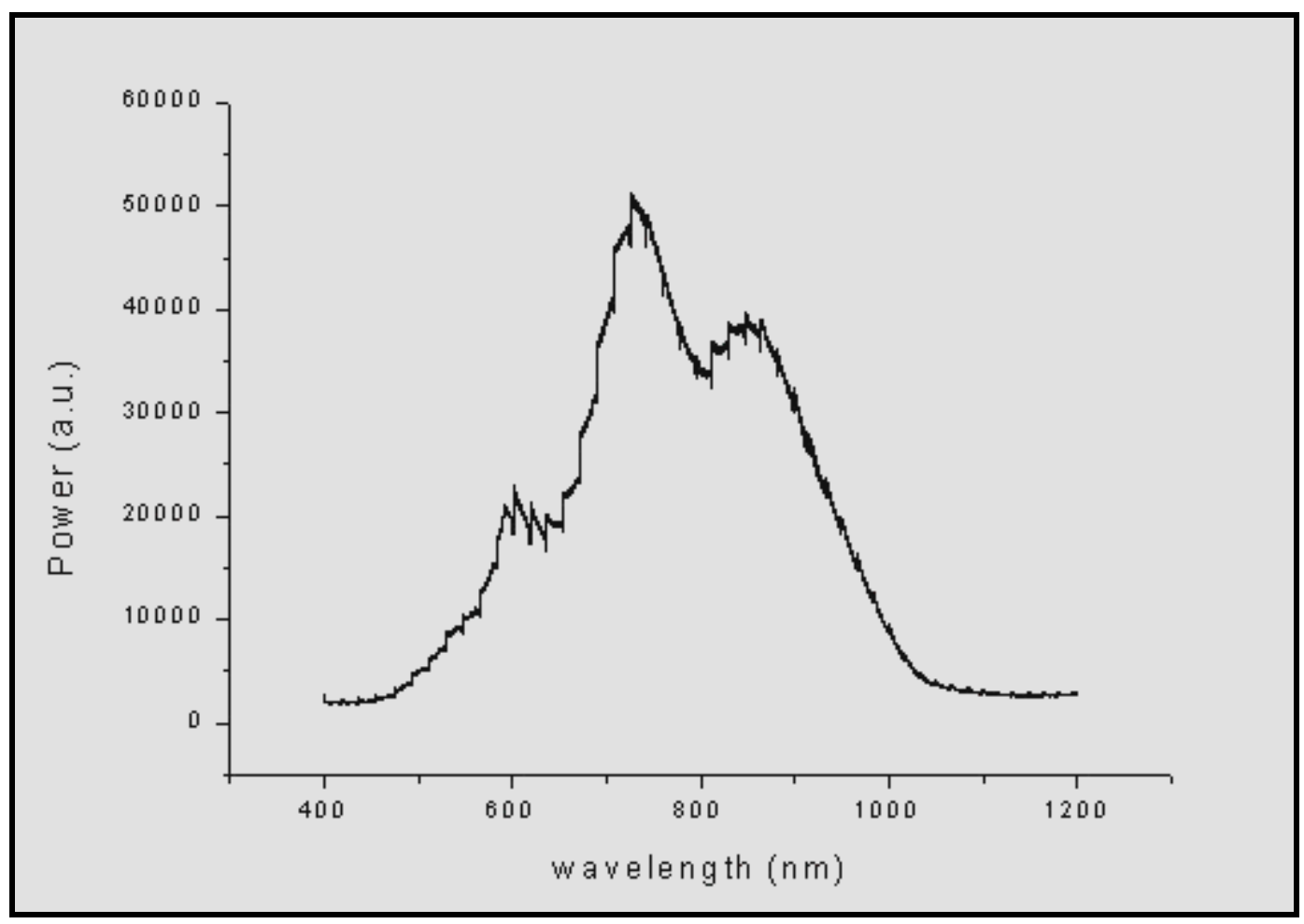

Figure 2.5. Halogen light spectrum

Table 2.1. Characteristics of light-emitting diode and halogen lights tested at B2 collection channel at Bonneville Dam in 2007

\begin{tabular}{llccccc}
\hline \multicolumn{1}{c}{ Model } & Emitted Color & $\begin{array}{c}\text { Intensity } \\
\text { (lumens) }\end{array}$ & $\begin{array}{c}\text { Total } \\
\text { Foot- } \\
\text { Candles }\end{array}$ & $\begin{array}{c}\text { Bulb Beam } \\
\text { Angle }\end{array}$ & $\begin{array}{c}\text { Peak } \\
\text { Wavelength } \\
\text { (nm) }\end{array}$ & $\begin{array}{c}\text { Bulb Life } \\
\text { (hr) }\end{array}$ \\
\hline $\begin{array}{l}\text { Light-emitting diode } \\
\text { R30-123-0AG-120AN }\end{array}$ & Aqua green & 390 & $2091 \mathrm{~cd}$ & $15 \mathrm{deg}$ & 525 & 100,000 \\
$\begin{array}{l}\text { Halogen } \\
\text { Sylvania (90 W) }\end{array}$ & White & 1350 & n/a & 25 deg flood & 710 & $2000-3000$ \\
\hline
\end{tabular}




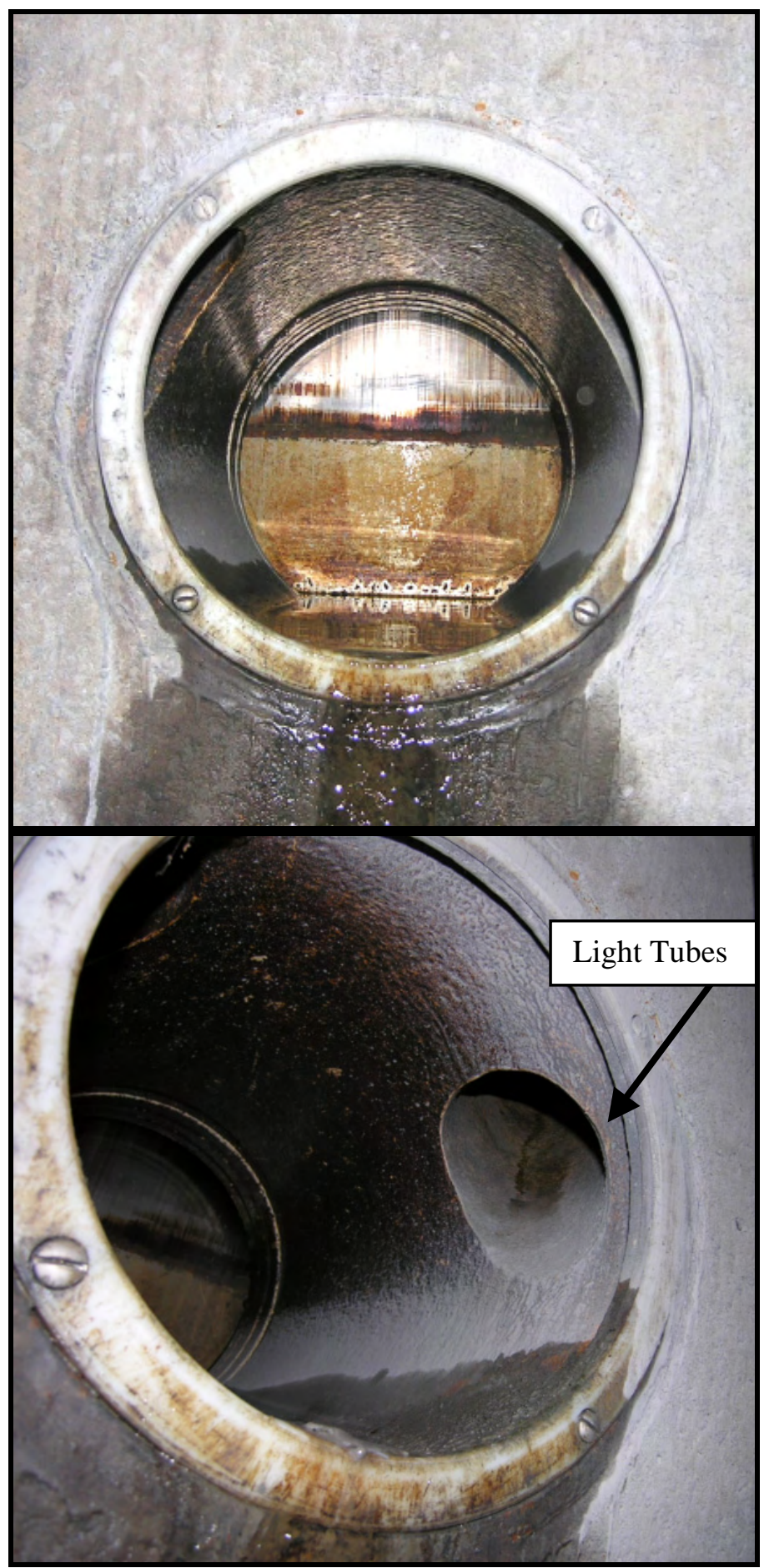

Figure 2.6. Dewatered closed orifice at north end of Gatewell 13B showing light tubes at orifice entrance 


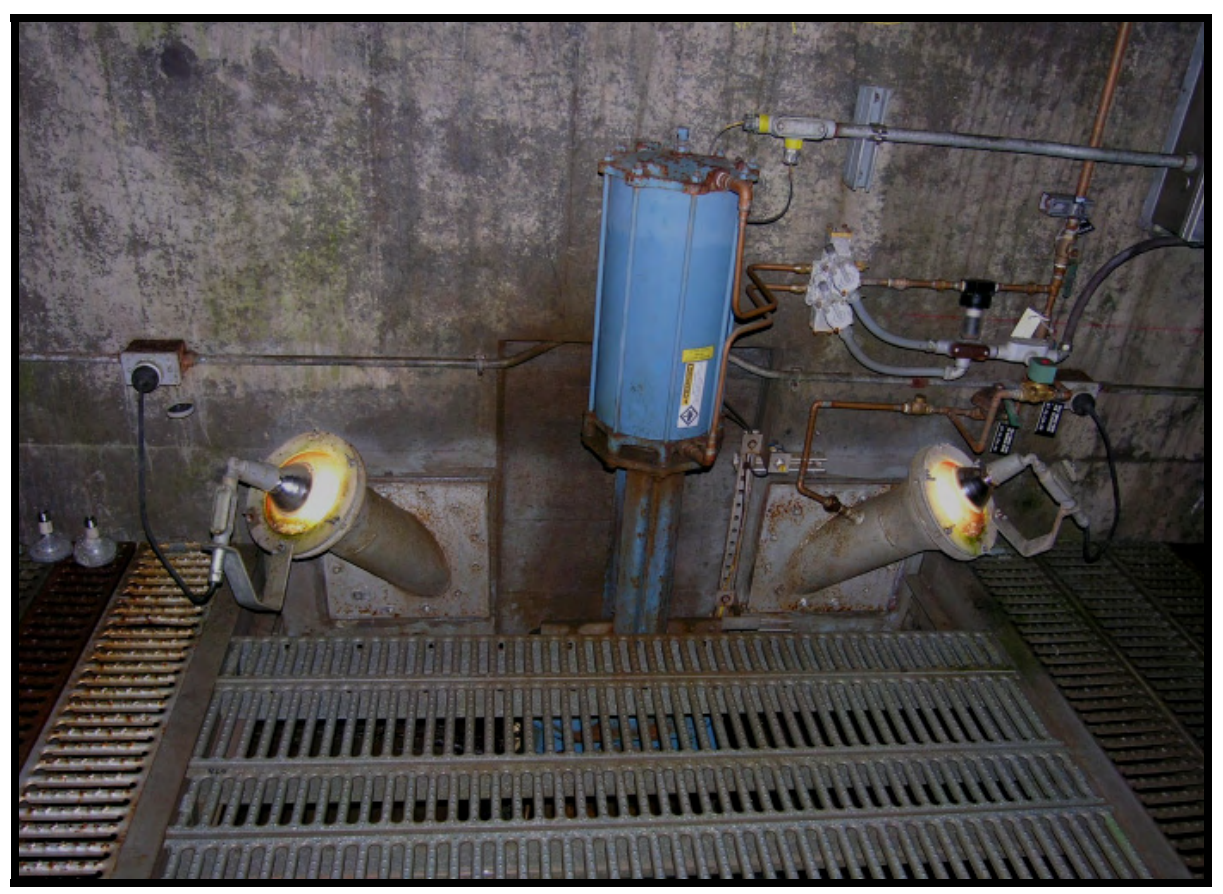

Figure 2.7. Top portion of light tubes in downstream migration channel with halogen lights installed

\section{Results}

\section{Field Study}

The water clarity was very good during the field measurement dates, with turbidity readings of 2.8 and 2.5 NTU and the Secchi disk reading of $7 \mathrm{ft}$ at the Bonneville Dam forebay. Ambient light levels were measured in the covered gatewell with the light sensor pointed upward at the water surface and at 2- to 4 -ft intervals down to $12 \mathrm{ft}$. The values were found to be fairly consistent and ranged from 0.32 to 0.5 lux (Figure 2.8). When the sensor was oriented to point north across the gatewell, the readings fell to 0.08 lux at a depth of $12 \mathrm{ft}$. A separate measurement of 12.8 lux was made at the deck level under the tarpaulins.

\section{Orifice Lighting Characterization}

Light intensity measurements for the LEDs with the sensor placed directly on axis with the orifice opening and just off the axis were generally very low. Only a slight improvement was noted when the dirty lenses were exchanged for the clean lenses (Figures 2.9 and 2.10). The highest value obtained with the LEDs was 0.65 lux at a distance of 2 in. from the opening. In comparison, the halogen lights produced the highest light level of 3.3 lux with the clean lens at the orifice opening, with a gradual loss of intensity out to a distance of 24 in. With a dirty (water-scaled) lens, the light intensity of the halogen was comparable to the LED light. When the sensor was 6 in. above the opening, the LED illumination output was slightly higher than when measured directly on axis (Figure 2.10). This small increase may be the result of light reflecting off the lower portion of the orifice and producing somewhat higher readings in this region (Figure 2.10). A small increase was observed also for the halogens. 


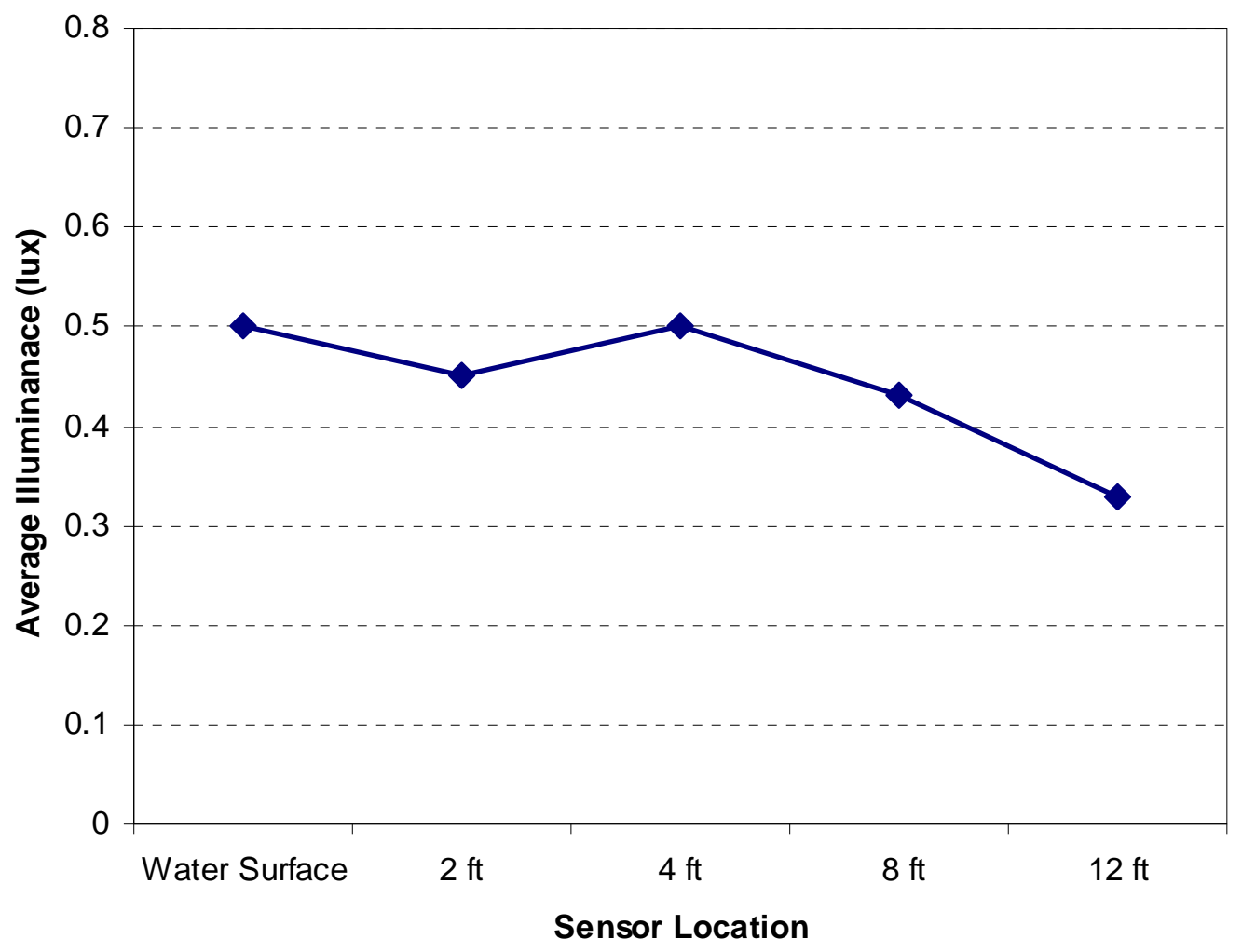

Figure 2.8. Ambient light levels measured within covered Gatewell 12A at various water depths

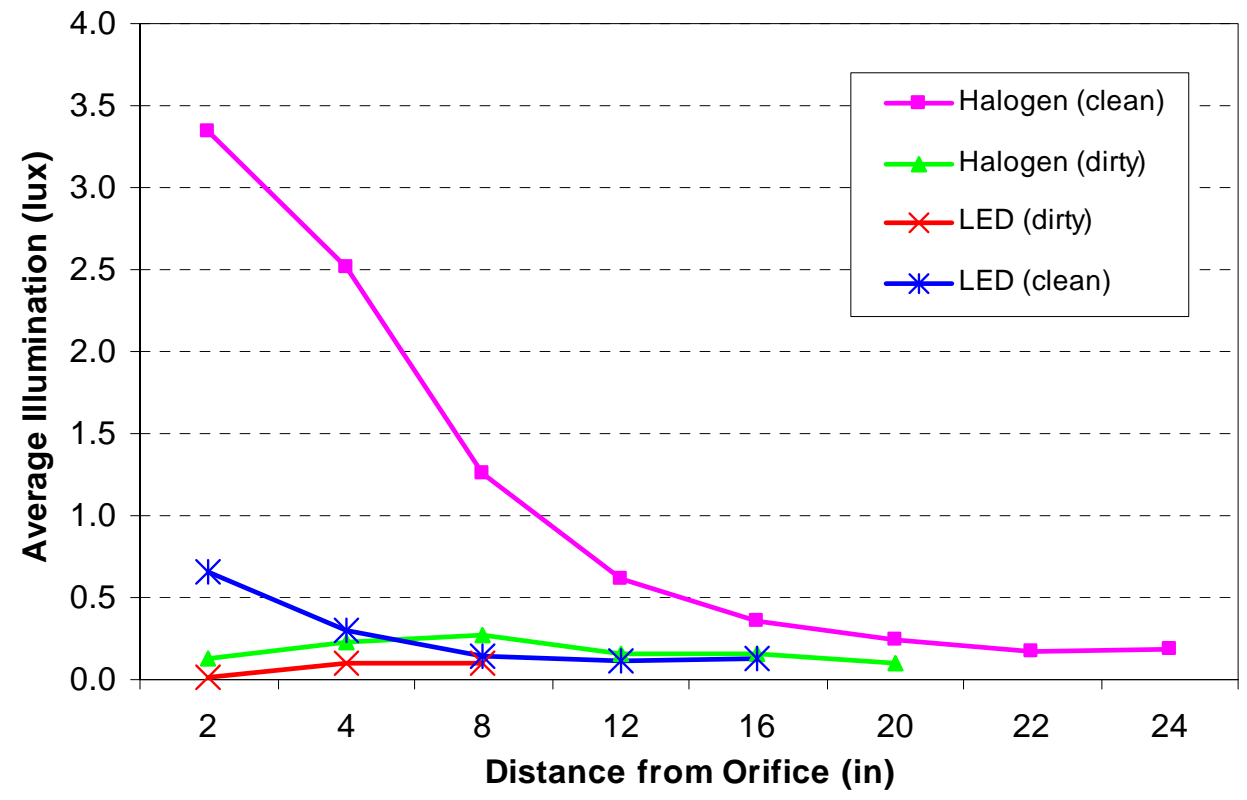

Figure 2.9. Light intensity measured at center of south orifice in Gatewell 12A for both light-emitting diode and halogen lamps using the clean and dirty lens caps 


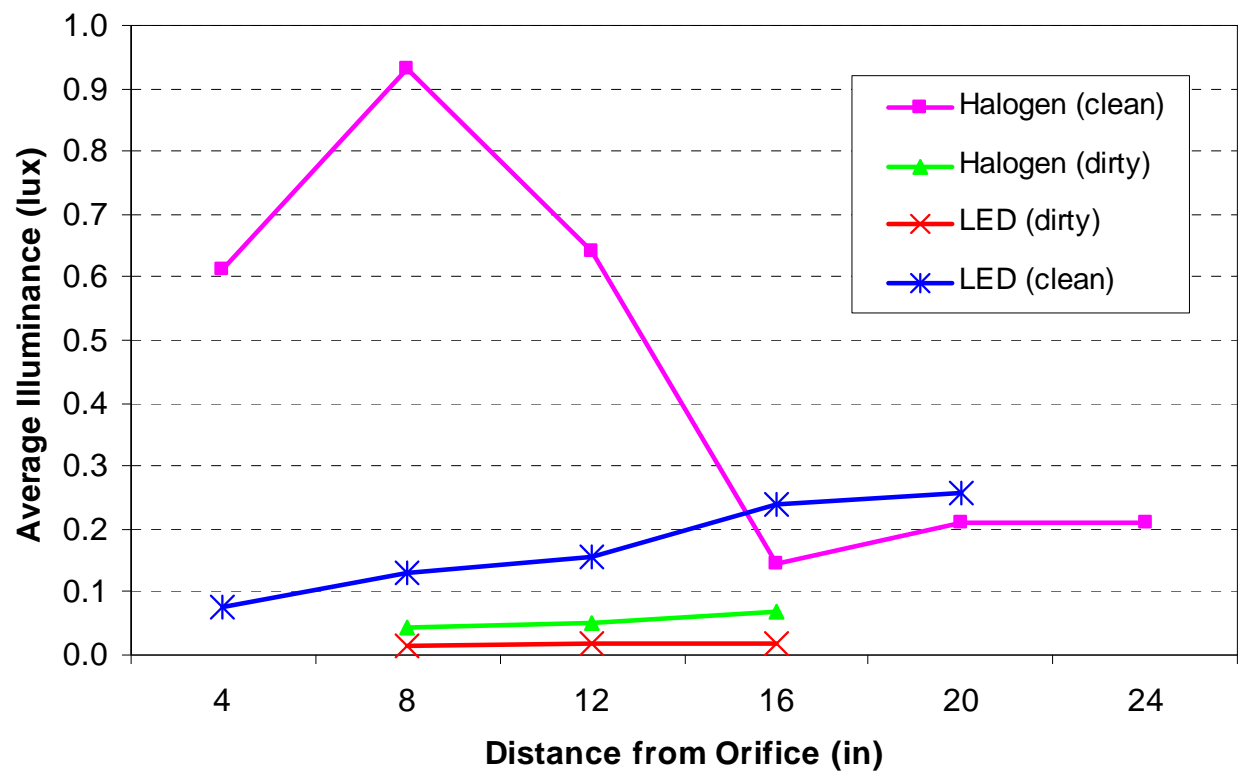

Figure 2.10. Light intensity measured 6 in. above top of south orifice in Gatewell 12A for both lightemitting diode and halogen lamps using the clean and dirty lens caps

Additional measurements were taken with the sensor placed $12 \mathrm{in.}$ from the south part of the orifice and oriented toward the orifice opening. The illumination profile shows a general reduction in light intensity out to at a range of 24 in. for the halogen and 18 in. for the LEDs (Figure 2.11).

\section{Laboratory Tests}

Laboratory tests were conducted to determine the intensity of the halogen, aqua green LED lamp, and a mercury vapor lamp with a clean clear glass lens and a water-scaled lens retrieved from the dam and used for the entire fish passage season (Figure 2.12). In addition to the halogen and LED flood lamp, a 100 -W mercury vapor bulb was tested. The bulb was powered using an external ballast. Measurements were taken in a darkened laboratory space on a bench top with the sensor placed on axis with the light at $54 \mathrm{in.}$ The in-water measurements were taken using a small raceway in which the light was placed $30 \mathrm{in.}$ above the water surface with the sensor placed at a depth of 15 in. using clear water.

The results show a substantial decrease in the output of the lamps when the water-scaled orifice tube lens cover was positioned at the light face (Table 2.2). The light loss was consistent for the LED and halogen lights, with a decrease in light intensity of 5 to 6 times. The light loss for the mercury lamp was only 2 times. Temperatures were taken at the face of each lamp to determine heat output. The resulting values were $143^{\circ} \mathrm{F}$ for the halogen, $74^{\circ} \mathrm{F}$ for the LED, and $250^{\circ} \mathrm{F}$ for the mercury vapor bulb. 


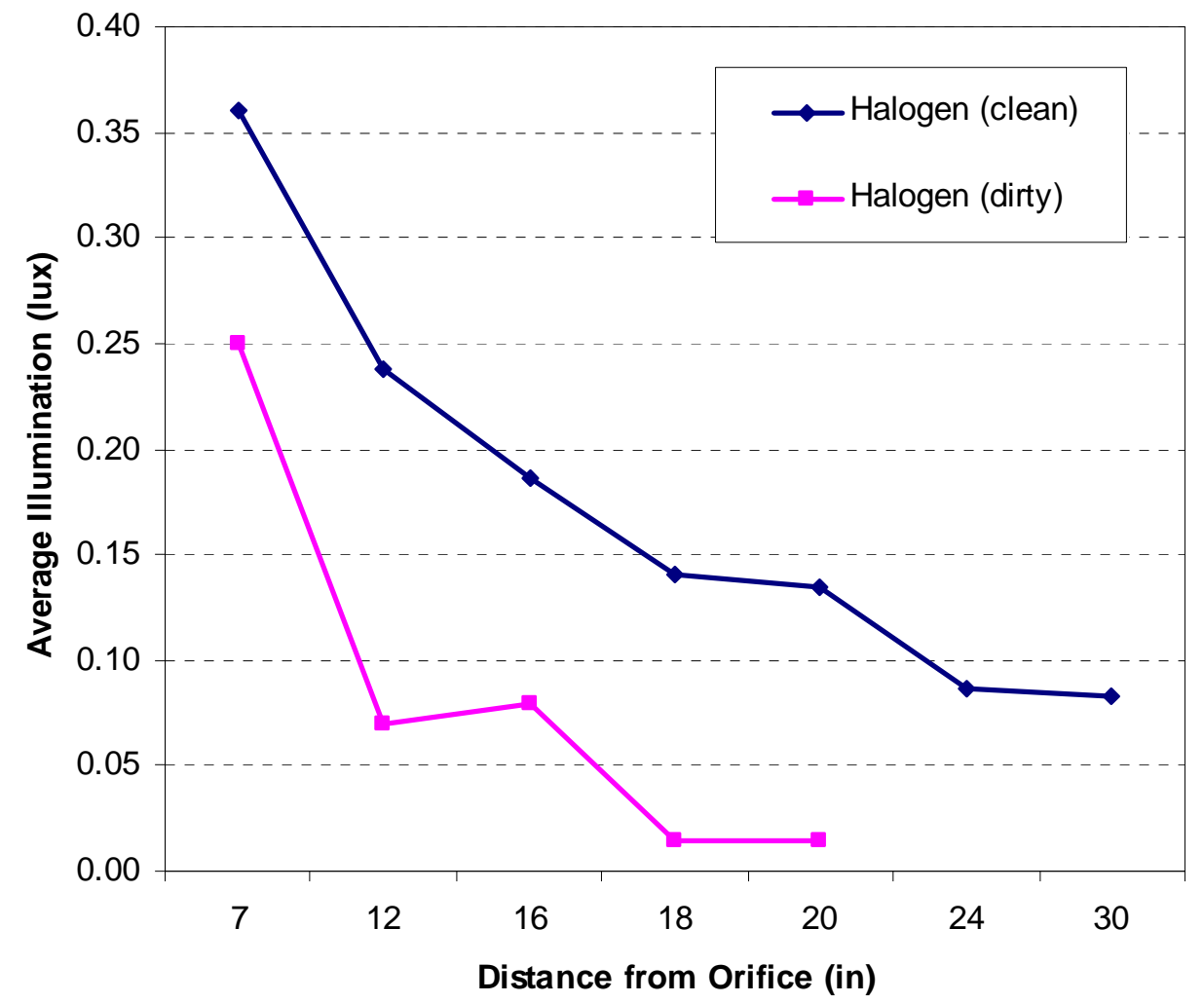

Figure 2.11. Light intensity with light sensor 12 in. from south end of orifice, sensor pointed toward north (toward orifice)

Table 2.2. Laboratory tests using three light sources in air and with light sensor in water using clean and water-scaled lens at light face (all values in lux)

\begin{tabular}{lccc}
\hline & \multicolumn{3}{c}{ In Air (54-in. spacing) } \\
\cline { 2 - 4 } \multicolumn{1}{c}{ Light Source } & Clean Lens Cover & Water-Scaled & Lens Cover \\
\hline 90-W halogen & 1811 & 365 & Light Loss Factor \\
\hline Aqua green LED & 347 & 59 & $5 \mathrm{x}$ \\
100-W mercury vapor & 670 & 334 & $6 \mathrm{x}$ \\
\hline & Lamp over Water (45-in. spacing with sensor 15 in. below water) \\
\cline { 2 - 4 } & & Water-Scaled & Light Loss Factor \\
\hline 90-W halogen & Clean Lens Cover & Lens Cover & $5.1 \mathrm{x}$ \\
Aqua green LED & 2200 & 430 & $6.3 \mathrm{x}$ \\
100-W mercury vapor & 550 & 86 & $1.9 \mathrm{x}$ \\
\hline
\end{tabular}




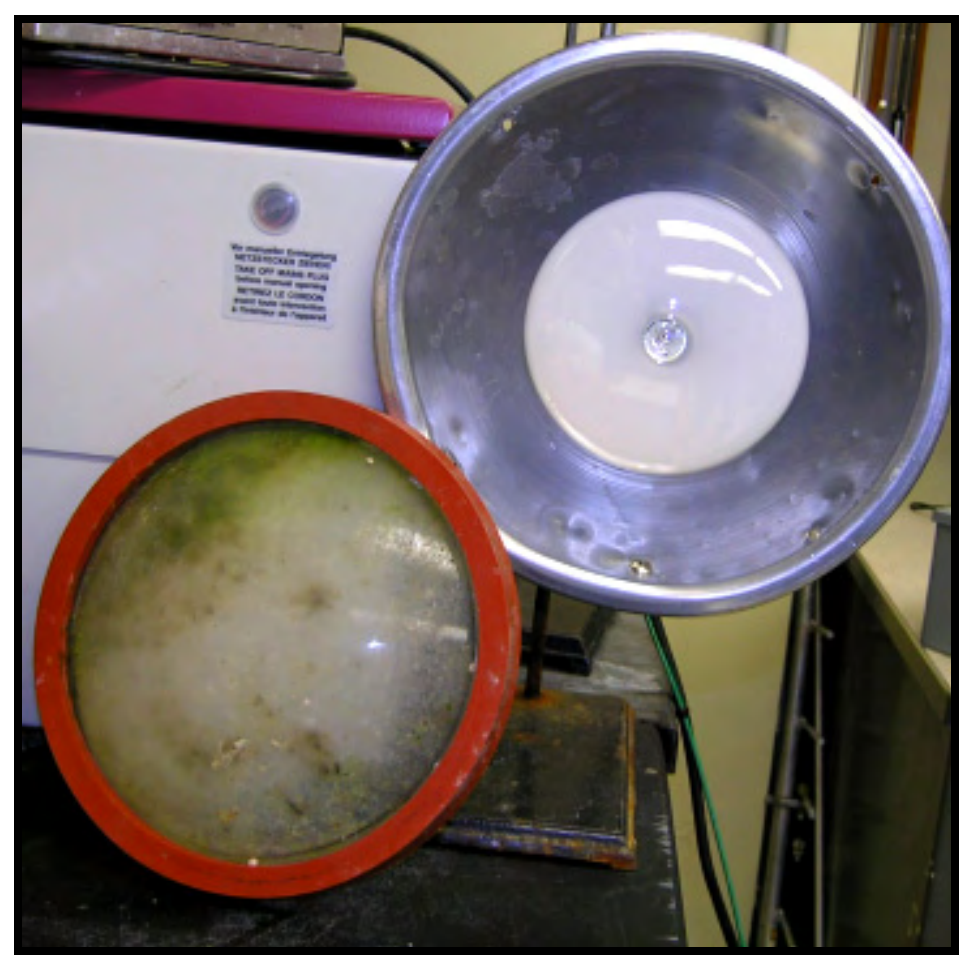

Figure 2.12. Water-scaled orifice tube lens cover (left); mercury vapor bulb with heat shield (right)

\section{Discussion}

Based on the field measurements at a single orifice in Gatewell 12, the existing light output from the LEDs in the immediate vicinity of the orifice opening was low, at approximately 0.1 lux with the dirty lens. Light output for the halogen light with the dirty lens was 0.25 lux at the opening. When the water-scaled lenses were exchanged for the clean ones, the readings rose to 0.6 lux for the LEDs and 3.25 lux for the halogen. For comparison, 1 lux is the amount of light produced by moonlight at high altitude, and 10 lux is the intensity of a candle at a distance of $1 \mathrm{ft}$. The halogen lights were far more effective at producing illumination near the orifice regions and outward to approximately 16 in. on axis with the opening where the values were similar to background measurements (ambient

light). The LEDs were far less effective at producing an illuminated region; this was especially evident when the water-scaled lens was used. When the sensor was positioned $12 \mathrm{in.} \mathrm{from} \mathrm{one} \mathrm{end} \mathrm{of} \mathrm{the} \mathrm{orifice,}$ light intensity for the halogen with the clean clear lens decreased by approximately a factor of 4 , from 1.5 (on axis) to 0.35 lux at 7 in. from the opening.

Water turbidity will influence to a large degree the illumination capability of any artificial light source. Water turbidities during the bulk of the smolt outmigration in the spring would be expected to be $3-5 \mathrm{ft}$ as measured with a Secchi disk. During the summer and fall, the water clarity generally improves to 6-7 ft. During the field tests at the B2 for this evaluation, the Secchi disk value was $7 \mathrm{ft}$. Generally, light at the longer wavelengths (red regions) would be better suited to penetrate the water than the shorter wavelengths, and white light produced by the halogen lamp would also be well suited for more turbid conditions.

The laboratory tests with the water-scaled lenses showed that the light loss for the halogen and the LEDs was 5-6 times in air and with the sensor placed in water. Output from the mercury vapor lamp when the water-scaled lens cap was placed at the light face was reduced by only a factor of two. The drawback to using the mercury vapor and the halogen is the amount of heat produced by the lens $\left(250^{\circ} \mathrm{F}\right.$ for the mercury vapor and $143^{\circ} \mathrm{F}$ for the halogen) and the reduced bulb life as compared to the LEDs. 


\section{References}

Ferguson JW, GM Matthews, RL McComas, RF Absolon, DA Brege, MH Gessel, and LG Gilbreath. 2005. Passage of Adult and Juvenile Salmonids through Federal Columbia River Power System Dams. NOAA Technical Memorandum NMFS-NWFSC-64, National Oceanic and Atmospheric Administration, U.S. Department of Commerce, Washington, D.C.

Monk BM, RF Absolon, BP Sandford, and JW Ferguson. 2002. Evaluation of Intake Modifications at

Bonneville Dam Second Powerhouse, 2001. Fish Ecology Division, Northwest Fisheries Science Center, Seattle, Washington. 


\section{Chapter 3}

\section{Recommendations}

Based on the information obtained from the literature search, juvenile salmonids can be attracted to illuminated regions during the nocturnal periods and can perceive light levels down to approximately

0.25 lux or $10^{-2} \mathrm{ft}-\mathrm{c}$, which equates to the light produced by moonlight. At the other end of the spectrum, previous researchers found that juvenile salmonids generally avoid or are startled when exposed to more intense light levels that correspond to daylight conditions or near 400 lux $\left(10^{-1.5} \mathrm{ft}-\mathrm{c}\right)$. The existing conditions for lighting placed above the orifice tubes in the DSM channel have proved to be less than ideal for light to penetrate the light tube and illuminate the orifice region. Based on the review of previous studies, a minimum luminance value of approximately 200-300 lux should be produced at the immediate orifice entrance. While some studies have shown that this light intensity could possibly startle test fish (when suddenly exposed) in controlled laboratory experiments, the values are expected to become less intense within a short distance from the orifice. Also, the expected higher water turbidity during the bulk of the spring outmigration would limit the light intensity.

Based on our study, some options for improving the lighting at the orifice entrances at the B2 include the following:

1. Incorporate a ring of LEDs that would be recessed into the orifice opening, thus eliminating the need for the light tubes. An automated cleaning system would also be required.

2. Incorporate the light source into the lens cap so that the cap and light housing is one waterproof unit. This would allow for all of the light to be directed into the light tube and eliminate the water scaling and debris-buildup issue, although water buildup could still pose a problem due to the splashing of water upward into the light tubes. Cleaning of the light and cap assembly also would be simplified.

3. Incorporate higher-intensity LED lamps. Several manufactures have developed high output LEDS which have been used in a variety of applications including automotive, flashlights, interior and exterior lighting and many industrial applications. These relatively new modules provide almost 50\% more light (some up to 250 lux) than a standard 5-W LED bulb. The cool white version have an expected 50,000-hour lifespan and have peak wavelengths of 440 and $550 \mathrm{~nm}$.

To evaluate the effectiveness of any modification to the existing system, tests could be conducted in which tagged fish are released in the gatewell with a light on/off scenario and the OPE evaluated. Different lighting could be used to test to determine if white light or light emitted within the peak action spectra of juvenile salmonids (blue-green region) is best for attracting fish near the orifice where the flow component is sufficient for entrainment into the collection channel. 
Appendix

Synopsis of Literature Reviewed 


\section{Appendix}

\section{Synopsis of Literature Reviewed}

\begin{tabular}{|c|c|c|c|c|c|c|}
\hline Reference & Study Objectives & Species & Life Stage & Experimental Conditions & Light Intensity & Results \\
\hline $\begin{array}{l}\text { Alexander G, R Sweeting, } \\
\text { and B McKeown (1994) }\end{array}$ & $\begin{array}{l}\text { Determine if the change } \\
\text { from a visual system } \\
\text { dominated by porphyropsin } \\
\text { to one dominated by } \\
\text { rhodopsin is one of the } \\
\text { developmental processes of } \\
\text { smoltification }\end{array}$ & Coho salmon & Juvenile (yearling) & $\begin{array}{l}\text { Fish were reared in outdoor } \\
\text { raceways; visual pigments } \\
\text { were extracted over a } \\
\text { 26-week period from } \\
\text { January } 21 \text { through July } 14 .\end{array}$ & Normal photoperiod & $\begin{array}{l}\text { The proportion of the two } \\
\text { visual pigments changed } \\
\text { during smoltification, } \\
\text { from porphyropsin- } \\
\text { dominated in pre-smolts to } \\
\text { rhodopsin-dominated in } \\
\text { the smolt stage. Change } \\
\text { can affect visual acuity. }\end{array}$ \\
\hline Ali MA (1959) & $\begin{array}{l}\text { Examination of the } \\
\text { ontogeny of photomechan- } \\
\text { ical and behavioral } \\
\text { responses of different } \\
\text { salmon species to light }\end{array}$ & $\begin{array}{l}\text { Sockeye, coho, } \\
\text { pink, and } \\
\text { chum }\end{array}$ & $\begin{array}{l}\text { Alevin through } \\
\text { smolt }\end{array}$ & $\begin{array}{l}\text { For adaptation rates (as } \\
\text { measured by the thickness } \\
\text { of the cones), fish were } \\
\text { either left in total darkness } \\
\text { or illuminated at } 400 \mathrm{ft}-\mathrm{c} \\
\text { overnight; samples were } \\
\text { taken between } 1 \text { and } \\
70 \text { min after exposure to } \\
\text { light or darkness; other } \\
\text { studies looked at feeding } \\
\text { rates and schooling times } \\
\text { after exposure to lights. } \\
\text { Retinal response, feeding } \\
\text { rates, and schooling } \\
\text { behavior were studied } \\
\text { under different light } \\
\text { intensities. }\end{array}$ & $\begin{array}{l}\text { Various: } 10^{2}, 10^{1} \text {, } \\
10^{0}, 10^{-1}, 10^{-2}, 10^{-3} \text {, } \\
10^{-4}, 10^{-5} \text {, and } \\
400 \mathrm{ft}-\mathrm{c}\end{array}$ & $\begin{array}{l}\text { As the fish became older, } \\
\text { time for light adaptation } \\
\text { decreased. The time for } \\
\text { dark adaptation increased } \\
\text { with age. The retinal } \\
\text { epithelial pigment for all } \\
\text { fish, except late pink fry, } \\
\text { had a latent period before } \\
\text { the start of contraction in } \\
\text { the dark. Species differ- } \\
\text { ences in retinal and } \\
\text { behavioral response to } \\
\text { light were noted. }\end{array}$ \\
\hline
\end{tabular}




\begin{tabular}{|c|c|c|c|c|c|c|}
\hline Reference & Study Objectives & Species & Life Stage & Experimental Conditions & Light Intensity & Results \\
\hline $\begin{array}{l}\text { Amaral SV, FC Winchell, } \\
\text { and TN Pearsons (2001) }\end{array}$ & $\begin{array}{l}\text { Determine if strobe light, } \\
\text { drop light, and infrasound } \\
\text { stimuli would divert } \\
\text { migrating fish to a } \\
\text { collection facility (Roza) }\end{array}$ & $\begin{array}{l}\text { Chinook } \\
\text { salmon, } \\
\text { pikeminnow, } \\
\text { smallmouth } \\
\text { bass }\end{array}$ & Smolt & $\begin{array}{l}\text { Exposure periods for the } \\
\text { drop lights were } 1 \text { or } 2 \text { min; } \\
\text { lights were either on } \\
\text { continuously or switched } \\
\text { on/off on a 1- or } 15-\text {-sec } \\
\text { interval. Fish were } \\
\text { evaluated with a test } \\
\text { channel positioned within } \\
\text { the river. Tests were } \\
\text { conducted during the day, } \\
\text { dusk, and at night (at night, } \\
\text { additional lights were used } \\
\text { to observe fish). }\end{array}$ & $\begin{array}{l}\text { None reported for } \\
500-W \text { SubSea light }\end{array}$ & $\begin{array}{l}\text { Weak avoidance response } \\
\text { noted to } 1 \text {-min drop light } \\
\text { test; at dusk and at night, } \\
\text { fish moved farther away } \\
\text { from the lights compared } \\
\text { to the control by } 0.3 \text { and } \\
0.13 \mathrm{~m} \text {, respectively, for } \\
1 \text { sec on/off, } 0.33 \text { and } 0.16 \\
\text { for the } 15 \text {-sec on/off, and } \\
0.06 \text { and } 0.5 \mathrm{~m} \text { for contin- } \\
\text { uous lights on. During the } \\
\text { day, fish were slightly } \\
\text { closer to the lights. For } \\
\text { the } 2 \text {-min treatment, there } \\
\text { was slight movement } \\
\text { away from the lights when } \\
\text { they were on continuously } \\
\text { at night. Most differences } \\
\text { were }<0.5 \text { m. }\end{array}$ \\
\hline $\begin{array}{l}\text { Beauchamp DA, } \\
\text { MF Shepard, and } \\
\text { GB Pauley (1983) }\end{array}$ & $\begin{array}{l}\text { The review is designed to } \\
\text { provide a brief, comprehen- } \\
\text { sive sketch of the biological } \\
\text { characteristics and environ- } \\
\text { mental requirements }\end{array}$ & $\begin{array}{l}\text { Chinook } \\
\text { salmon }\end{array}$ & All & & & \\
\hline $\begin{array}{l}\text { Beeman JW and } \\
\text { AG Maule (2001) }\end{array}$ & $\begin{array}{l}\text { Evaluate residence times } \\
\text { within a portion of the fish } \\
\text { collection system at } \\
\text { McNary Dam }\end{array}$ & $\begin{array}{l}\text { Chinook } \\
\text { salmon and } \\
\text { steelhead trout }\end{array}$ & Juvenile & $\begin{array}{l}\text { Fish were radio-tagged and } \\
\text { released individually into } \\
\text { the gatewell during the } \\
\text { daytime ( } 1130 \text { hours) and } \\
\text { evening ( } 2000 \text { hours) }\end{array}$ & Ambient & $\begin{array}{l}\text { Median gatewell residence } \\
\text { times were } 8.9 \mathrm{hr} \text { for } \\
\text { Chinook and } 3.2 \mathrm{hr} \text { for } \\
\text { steelhead. Most fish } \\
\text { passed through the gate- } \\
\text { well to the collection } \\
\text { channel during the evening, } \\
\text { regardless of release time. }\end{array}$ \\
\hline $\begin{array}{l}\text { Brett JR and } \\
\text { D MacKinnon (1953) }\end{array}$ & $\begin{array}{l}\text { Evaluate the effectiveness } \\
\text { of a bubble curtain and } \\
\text { lights in deflecting fish }\end{array}$ & $\begin{array}{l}\text { Chinook } \\
\text { salmon }\end{array}$ & $\begin{array}{l}\text { Under-yearling } \\
\text { (average length = } \\
58 \mathrm{~mm} \text { ) }\end{array}$ & $\begin{array}{l}\text { In canal, fish were exposed } \\
\text { to a bubble curtain and/or } \\
\text { either continuously on or } \\
\text { flashing lights. Fish were } \\
\text { captured using paired nets; } \\
\text { the nets were set between } \\
\text { 8:30 and 9:30 p.m. and left } \\
\text { in place for 3-4 hours. }\end{array}$ & $\begin{array}{l}3.5 \mathrm{ft}-\mathrm{c} \text { at the water } \\
\text { surface. Flash rate } \\
\text { was } 1 / \mathrm{s} \text {. }\end{array}$ & $\begin{array}{l}\text { More than two-thirds of the } \\
\text { fish were deflected away } \\
\text { from the lights; the flashing } \\
\text { lights appeared to be more } \\
\text { effective in diverting fish } \\
\text { than the continuously on } \\
\text { lights ( } 74 \% \text { vs. } 68 \% \text { ). The } \\
\text { bubble curtain did not } \\
\text { appear to be effective in } \\
\text { diverting fish. }\end{array}$ \\
\hline
\end{tabular}




\begin{tabular}{|c|c|c|c|c|c|c|}
\hline Reference & Study Objectives & Species & Life Stage & Experimental Conditions & Light Intensity & Results \\
\hline $\begin{array}{l}\text { Congleton JL and } \\
\text { EJ Wagner (1988) }\end{array}$ & $\begin{array}{l}\text { Determine plasma cortisol } \\
\text { responses to passage } \\
\text { through three prototype } \\
\text { flumes that could be used to } \\
\text { replace pressurized-pipe } \\
\text { bypasses at dams on the } \\
\text { Columbia and Snake rivers }\end{array}$ & $\begin{array}{l}\text { Chinook } \\
\text { salmon and } \\
\text { steelhead trout }\end{array}$ & Smolt & $\begin{array}{l}\text { Three flume designs (small } \\
\text { baffled, large baffled, and } \\
\text { unbaffled with corruga- } \\
\text { tions) were tested under } \\
\text { three conditions (nighttime, } \\
\text { partly darkened in the } \\
\text { daytime, completely } \\
\text { darkened in daytime. }\end{array}$ & $\begin{array}{l}\text { Partially darkened: } \\
\text { 400-900 lux; } \\
\text { completely darkened } \\
\text { daytime: } 1-4 \text { lux }\end{array}$ & $\begin{array}{l}\text { Plasma cortisol levels were } \\
\text { higher at night for fish } \\
\text { passing through the flumes. } \\
\text { During the day, Chinook } \\
\text { smolts going through the } \\
\text { darkened flume had the } \\
\text { lowest levels, while fish } \\
\text { going through uncovered } \\
\text { flumes had the highest } \\
\text { levels. For steelhead, } \\
\text { cortisol levels were highest } \\
\text { during the day, regardless } \\
\text { of light levels. }\end{array}$ \\
\hline $\begin{array}{l}\text { Connor WP, } \\
\text { RK Steinhorst, and } \\
\text { HL Burge (2003) }\end{array}$ & $\begin{array}{l}\text { Describe the migrational } \\
\text { behavior of fall Chinook } \\
\text { salmon from shoreline } \\
\text { rearing to migration down } \\
\text { the Snake River. Analyze } \\
\text { the effects of flow, tempera- } \\
\text { ture, initial tagging date, } \\
\text { fork length, and distance } \\
\text { traveled on migration rate. }\end{array}$ & $\begin{array}{l}\text { Chinook } \\
\text { salmon }\end{array}$ & Fry to smolt & $\begin{array}{l}\text { Fish were captured between } \\
\text { April and June/July and } \\
\text { PIT-tagged. Tagged fish } \\
\text { were released at capture } \\
\text { sites; fish were recaptured } \\
\text { using either beach seines or } \\
\text { detected passing Lower } \\
\text { Granite Dam. }\end{array}$ & Not applicable & $\begin{array}{l}\text { Fall Chinook passes } \\
\text { through four migrational } \\
\text { phases: 1) discontinuous } \\
\text { downstream dispersal } \\
\text { along the shoreline; } \\
\text { 2) abrupt and mostly con- } \\
\text { tinuous dispersal offshore; } \\
\text { 3) passive, discontinuous } \\
\text { downstream dispersal } \\
\text { offshore; and 4) active and } \\
\text { mostly continuous } \\
\text { seaward migration. }\end{array}$ \\
\hline $\begin{array}{l}\text { Deutschlander ME, } \\
\text { DK Greaves, } \\
\text { TJ Haimberger, and } \\
\text { CW Hawryshyn (2001) }\end{array}$ & $\begin{array}{l}\text { Map the ultraviolet } \\
\text { sensitivity topographically } \\
\text { during smoltification }\end{array}$ & $\begin{array}{l}\text { Rainbow and } \\
\text { steelhead trout }\end{array}$ & $\begin{array}{l}\text { Rainbow parr and } \\
\text { steelhead smolt }\end{array}$ & $\begin{array}{l}\text { Rainbow parr were exposed } \\
\text { to thyroxine; steelhead } \\
\text { smolts were assessed for } \\
\text { ultraviolet sensitivity. }\end{array}$ & $\begin{array}{l}\text { Spectral sensitivity } \\
\text { was determined at } \\
\text { increasing intensities } \\
\text { of monochromatic } \\
\text { light flashes for } 12 \\
\text { wavelengths ( } 350- \\
650 \mathrm{~nm} \text { ). }\end{array}$ & $\begin{array}{l}\text { Ultraviolet visual } \\
\text { sensitivity appears to be } \\
\text { reduced and possibly lost } \\
\text { during smoltification in } \\
\text { anadromous salmonids. } \\
\text { Reduction in ultraviolet } \\
\text { sensitivity occurs in the } \\
\text { ventral retina. }\end{array}$ \\
\hline
\end{tabular}




\begin{tabular}{|c|c|c|c|c|c|c|}
\hline Reference & Study Objectives & Species & Life Stage & Experimental Conditions & Light Intensity & Results \\
\hline Fields PE (1966) & $\begin{array}{l}\text { Experiments at McNary and } \\
\text { The Dalles dams looking at } \\
\text { the behavioral response of } \\
\text { juvenile salmon to light }\end{array}$ & $\begin{array}{l}\text { Salmon (no } \\
\text { species given) } \\
\text { and steelhead }\end{array}$ & $\begin{array}{l}\text { Downstream } \\
\text { migrating }\end{array}$ & $\begin{array}{l}\text { Lights were placed to guide } \\
\text { fish toward or away from } \\
\text { structures }\end{array}$ & $\begin{array}{l}\text { No intensity } \\
\text { measured, just } \\
\text { wattage of light } \\
\text { sources }\end{array}$ & $\begin{array}{l}\text { Variable results, depend- } \\
\text { ing on placement of lights } \\
\text { and flows, time of day, } \\
\text { and season. In general, } \\
\text { dark-adapted smolts } \\
\text { avoided lights; fish that } \\
\text { have previous exposure to } \\
\text { light were attracted to light } \\
\text { if the intensity of the light } \\
\text { was reduced relative to the } \\
\text { adaptation light. Velocity } \\
\text { was the single most } \\
\text { important factor affecting } \\
\text { downstream migrants. }\end{array}$ \\
\hline $\begin{array}{l}\text { Fields PE, AK Murray, } \\
\text { DE Johnson, and } \\
\text { GL Finger (1958) }\end{array}$ & $\begin{array}{l}\text { Evaluate the effect of } \\
\text { ambient light conditions on } \\
\text { the response to a light } \\
\text { barrier }\end{array}$ & $\begin{array}{l}\text { Silver (coho) } \\
\text { salmon }\end{array}$ & $\begin{array}{l}\text { Yearling (migratory } \\
\text { size) }\end{array}$ & $\begin{array}{l}\text { Environmental light } \\
\text { intensities were paired with } \\
\text { barrier light intensities. } \\
\text { Each trial lasted } 5 \text { min, } \\
\text { after which the position of } \\
\text { the fish was noted ( } 25 \text { fish } \\
\text { per test). }\end{array}$ & $\begin{array}{l}\text { Environmental light } \\
\text { intensity (ft-c): } 0 \text { to } \\
60 \text {; barrier light } \\
\text { levels: } 10,20 \text {, and } \\
40 \mathrm{ft}-\mathrm{c} .\end{array}$ & $\begin{array}{l}\text { Dark-adapted fish tested } \\
\text { under maximum contrast } \\
\text { had the highest avoidance } \\
\text { response; light adaptation } \\
\text { reduced negative } \\
\text { phototaxis. }\end{array}$ \\
\hline $\begin{array}{l}\text { Finger GL and PE Fields } \\
\text { (1957) }\end{array}$ & $\begin{array}{l}\text { Effectiveness of lights with } \\
\text { respect to flow and turbidity }\end{array}$ & $\begin{array}{l}\text { Silver (coho) } \\
\text { and Chinook } \\
\text { salmon }\end{array}$ & $\begin{array}{l}\text { Yearling (migratory } \\
\text { size) }\end{array}$ & $\begin{array}{l}\text { Report covers several sets } \\
\text { of experiments conducted } \\
\text { in situ. }\end{array}$ & $\begin{array}{l}0,75 \text {, and } 300 \mathrm{~W} \text { (no } \\
\text { intensity given) }\end{array}$ & $\begin{array}{l}\text { As turbidity increased the } \\
\text { number of fish collected in } \\
\text { the dark trap declined } \\
\text { from } 92 \% \text { to } 16 \% \text { (run } \\
\text { magnitude was also } \\
\text { increasing) at night. } \\
\text { During the day, fish } \\
\text { appeared to be attracted to } \\
\text { the } 75-W \text { trap and slightly } \\
\text { repelled by the } 300-W \text {. A } \\
\text { dim light ( } 0.015 \mathrm{ft}-\mathrm{c} \text { ) } \\
\text { attracted fish in both clear } \\
\text { and very turbid water. }\end{array}$ \\
\hline
\end{tabular}




\begin{tabular}{|c|c|c|c|c|c|c|}
\hline Reference & Study Objectives & Species & Life Stage & Experimental Conditions & Light Intensity & Results \\
\hline Hays SG (1988) & $\begin{array}{l}\text { Study evaluated avoidance } \\
\text { behavior near a submersible } \\
\text { traveling screen at Rocky } \\
\text { Reach Dam. A separate } \\
\text { laboratory study was carried } \\
\text { out to evaluate the use of } \\
\text { strobe lights on salmon and } \\
\text { steelhead behavior; results } \\
\text { are summarized in this } \\
\text { report. }\end{array}$ & $\begin{array}{l}\text { Salmon (no } \\
\text { species given) } \\
\text { and steelhead }\end{array}$ & & & Strobe lights & $\begin{array}{l}\text { The sudden appearance of } \\
\text { a strobe light produced } \\
\text { escape speeds of about } \\
7 \text { body lengths per second. } \\
\text { However, fish were } \\
\text { observed to maintain } \\
\text { position or follow the } \\
\text { penumbra (the edge of the } \\
\text { beam where the intensity } \\
\text { was less). }\end{array}$ \\
\hline $\begin{array}{l}\text { Hoar WS, } \\
\text { MHA Keenleyside, and } \\
\text { RG Goodall (1957) }\end{array}$ & $\begin{array}{l}\text { Study the response of } \\
\text { several species of salmonids } \\
\text { to various light intensities }\end{array}$ & $\begin{array}{l}\text { Pink, chum, } \\
\text { coho, sockeye }\end{array}$ & Fry and smolt & $\begin{array}{l}\text { Several sets of experiments } \\
\text { were conducted. The first } \\
\text { was conducted in an } \\
\text { aquarium subdivided into } \\
\text { an illuminated and a } \\
\text { darkened half; lights were } \\
\text { turned on and intensity } \\
\text { increased in at 10-min } \\
\text { intervals. In the second, } \\
\text { fish were exposed to lights } \\
\text { combined with water flow } \\
\text { and turbulence. In a third } \\
\text { experiment, fish were } \\
\text { studied in a tall tank to look } \\
\text { at vertical movement. }\end{array}$ & $\begin{array}{l}\text { Light intensity varied } \\
\text { from } 10 \text { to } 1000 \mathrm{ft}-\mathrm{c}\end{array}$ & $\begin{array}{l}\text { In no case was the } \\
\text { response all or none; after } \\
\text { an initial startle response, } \\
\text { fish would pass between } \\
\text { the light and dark areas of } \\
\text { the tank. Species differ- } \\
\text { ences were noted: chum } \\
\text { and pink preferred the } \\
\text { light, while sockeye fry } \\
\text { retreated to darker areas } \\
\text { and coho appeared } \\
\text { indifferent to moderately } \\
\text { high light levels. Differ- } \\
\text { ences were noted also } \\
\text { between hatchery and wild } \\
\text { salmon of the same } \\
\text { species. }\end{array}$ \\
\hline $\begin{array}{l}\text { Hoffnagle TL and } \\
\text { AJ Fivizzani, Jr. (1988) }\end{array}$ & $\begin{array}{l}\text { Determine whether salmon } \\
\text { can alter smoltification } \\
\text { hormones in response to } \\
\text { changes in photoperiod }\end{array}$ & $\begin{array}{l}\text { Chinook } \\
\text { salmon }\end{array}$ & $\begin{array}{l}\text { Juvenile fall } \\
\text { Chinook }\end{array}$ & $\begin{array}{l}\text { Held between March } 10 \\
\text { and June } 3 \text { under three light } \\
\text { conditions: } 24 \mathrm{hr} \text { light; } \\
9 \text { hr light-15 hr dark; and } \\
\text { increasing photoperiod } \\
\text { (from } 10 \mathrm{hr} \text { light to } 15.5 \mathrm{hr} \\
\text { light at end) }\end{array}$ & $\begin{array}{l}\text { Broad-spectrum } \\
\text { fluorescent light } \\
40 \mathrm{~cm} \text { above the } \\
\text { surface; light } \\
\text { intensity at surface } \\
\text { was } 55 \text { lux. }\end{array}$ & $\begin{array}{l}\text { Natural photoperiod group } \\
\text { had a more coordinated } \\
\text { and complete smoltifica- } \\
\text { tion based on highest } \\
\text { mean and peak levels of } \\
\text { both thyroxine and } \\
\text { cortisol, greatest decrease } \\
\text { in hepatosomatic index, } \\
\text { greatest decrease in the } \\
\text { condition factor, and least } \\
\text { decrease in hematocrit. }\end{array}$ \\
\hline
\end{tabular}




\begin{tabular}{|c|c|c|c|c|c|c|}
\hline Reference & Study Objectives & Species & Life Stage & Experimental Conditions & Light Intensity & Results \\
\hline Iwata M (1995) & $\begin{array}{l}\text { Review of downstream } \\
\text { migratory behavior and its } \\
\text { relationship to cortisol and } \\
\text { thyroid hormones }\end{array}$ & $\begin{array}{l}\text { Chum and } \\
\text { coho }\end{array}$ & Fry, smolt & & & $\begin{array}{l}\text { Chum fry and coho smolts } \\
\text { changed preference from } \\
\text { shade to open water after } \\
\text { exposure to thyroid } \\
\text { hormones. }\end{array}$ \\
\hline $\begin{array}{l}\text { Kelly DJ and ML } \\
\text { Bothwell (2002) }\end{array}$ & $\begin{array}{l}\text { Determine if fish selectively } \\
\text { avoid UV radiation and } \\
\text { gauge the importance of } \\
\text { UVA and UVB wavelengths } \\
\text { in photo-avoidance behavior }\end{array}$ & Coho salmon & $\begin{array}{l}\text { Alevin and pre- } \\
\text { smolt }\end{array}$ & $\begin{array}{l}\text { Outdoor, in-stream } \\
\text { enclosures covered with } \\
\text { different combinations of } \\
\text { two solar exclusion panels; } \\
\text { cloudless and cloudy days }\end{array}$ & $\begin{array}{l}4 \text { solar exclusion } \\
\text { panels: PAR }(400- \\
700 \mathrm{~nm}) ; \text { PAR + } \\
\text { UVA (320-400 nm); } \\
\text { PAR + UVA + UVB } \\
(280-320 \mathrm{~nm}) \text { and } \\
50 \%(\text { PAR + UVA + } \\
\text { UVB) }\end{array}$ & $\begin{array}{l}\text { Under sunny conditions, } \\
\text { coho alevins showed } \\
\text { significant preference for } \\
\text { PAR and 50\% (PAR+ } \\
\text { UVA+UVB), and juvenile } \\
\text { coho showed significant } \\
\text { preference for the absence } \\
\text { of UV radiation. Under } \\
\text { cloudy skies, juvenile } \\
\text { coho showed no prefer- } \\
\text { ence for any of the } \\
\text { treatments. }\end{array}$ \\
\hline $\begin{array}{l}\text { Kemp PS, MH Gessel, } \\
\text { and JG Williams (2005) }\end{array}$ & $\begin{array}{l}\text { Assess the capability of fall } \\
\text { Chinook salmon smolts to } \\
\text { recognize and avoid or } \\
\text { choose areas with overhead } \\
\text { cover during downstream } \\
\text { migration }\end{array}$ & $\begin{array}{l}\text { Chinook } \\
\text { salmon }\end{array}$ & Smolt & $\begin{array}{l}\text { Experimental flume at } \\
\text { McNary Dam; overhead } \\
\text { drop lighting illuminated } \\
\text { the flume, while a cover } \\
\text { positioned } 0.65 \mathrm{~m} \text { above } \\
\text { the water surface provided } \\
\text { shade along one-half. }\end{array}$ & None reported & $\begin{array}{l}\text { Approximately } 80 \% \text { of the } \\
\text { migrating smolts avoided } \\
\text { the covered channel and } \\
\text { selected the uncovered } \\
\text { half. }\end{array}$ \\
\hline Long CW (1968) & $\begin{array}{l}\text { Determine the timing and } \\
\text { distribution of fingerling } \\
\text { salmon entering turbine } \\
\text { intakes at The Dalles and } \\
\text { McNary dams on the } \\
\text { Columbia River }\end{array}$ & $\begin{array}{l}\text { Chinook } \\
\text { salmon and } \\
\text { steelhead trout }\end{array}$ & Juvenile & $\begin{array}{l}\text { Fyke nets were fished at the } \\
\text { center intake of turbines at } \\
\text { the ends and middle of the } \\
\text { powerhouse at The Dalles } \\
\text { and at intake C of Unit } 12 \\
\text { at McNary. At The Dalles, } \\
\text { nets were set to look at diel } \\
\text { and vertical distributions, } \\
\text { while at McNary, nets were } \\
\text { set at night to look at the } \\
\text { vertical distribution. }\end{array}$ & Not applicable & $\begin{array}{l}\text { All age groups and species } \\
\text { were more abundant at } \\
\text { night than during the day; } \\
\text { the I-group salmonids } \\
\text { were significantly more } \\
\text { plentiful (94\% of the } \\
\text { I-group Chinook and 85\% } \\
\text { of the I-group steelhead } \\
\text { were caught at night. } \\
\text { Vertically, most fish were } \\
\text { caught in the top two of } \\
\text { the six nets. The I-group } \\
\text { Chinook and the I-group } \\
\text { steelhead were most } \\
\text { strongly concentrated in } \\
\text { the top (73\% and } 74 \%) \text {. }\end{array}$ \\
\hline
\end{tabular}




\begin{tabular}{|c|c|c|c|c|c|c|}
\hline Reference & Study Objectives & Species & Life Stage & Experimental Conditions & Light Intensity & Results \\
\hline $\begin{array}{l}\text { Marquette W, F } \\
\text { Ossiander, R Duncan, C } \\
\text { Lond, and RF Krema } \\
\text { (1970) }\end{array}$ & $\begin{array}{l}\text { Measure the effect of } \\
\text { illumination of the gatewells } \\
\text { and orifices on the passage } \\
\text { of salmonids into the } \\
\text { sluiceway at McNary Dam }\end{array}$ & $\begin{array}{l}\text { Chinook, } \\
\text { coho, and } \\
\text { sockeye } \\
\text { salmon; } \\
\text { steelhead trout }\end{array}$ & Smolt & $\begin{array}{l}\text { Test conditions were } \\
\text { covered (i.e., dark) or } \\
\text { uncovered gatewells and } \\
\text { dark or lighted orifices. } \\
\text { Light for orifice was either } \\
\text { ambient or a } 150-W \\
\text { floodlight placed } 1 \mathrm{ft} \text { above } \\
\text { the orifice exit. }\end{array}$ & Not given & $\begin{array}{l}\text { Retention in the gatewell } \\
\text { was less for all species } \\
\text { when the gatewell was } \\
\text { darkened. Coho salmon } \\
\text { and steelhead trout } \\
\text { showed no preference for } \\
\text { orifice lighting, while } \\
\text { Chinook salmon preferred } \\
\text { the lighted orifice. }\end{array}$ \\
\hline $\begin{array}{l}\text { Nemeth RS and } \\
\text { JJ Anderson (1992) }\end{array}$ & $\begin{array}{l}\text { Investigate fish behavior } \\
\text { with exposure to mercury } \\
\text { vapor and strobe lights } \\
\text { under a variety of ambient } \\
\text { lighting conditions. Deter- } \\
\text { mine if differences in } \\
\text { ambient lighting altered } \\
\text { initial and subsequent } \\
\text { behavior in response to } \\
\text { strobe and mercury lights. }\end{array}$ & $\begin{array}{l}\text { Coho and } \\
\text { Chinook }\end{array}$ & $\begin{array}{l}\text { Juvenile (pre-smolt } \\
\text { to smolt) }\end{array}$ & $\begin{array}{l}\text { Day and night tests (April- } \\
\text { June); fish were adapted to } \\
\text { one of four conditions } \\
\text { (daytime, nighttime, dark- } \\
\text { adapted; light-adapted); } \\
\text { fish were exposed to strobe } \\
\text { or mercury lights and } \\
\text { behavior monitored for } \\
1 \text { hr. }\end{array}$ & $\begin{array}{l}\text { Units: microein- } \\
\left.\text { steins } / \mathrm{m}^{2} / \mathrm{s}\right) \text {. } \\
\text { Adaptation levels: } \\
\text { daytime ( } 1 \text { to }>1000) \text {; } \\
\text { nighttime (dusk to } \\
\text { complete darkness); } \\
\text { light-adapted (5). } \\
\text { Test levels: mercury } \\
\text { lights }(100 \text { at } 1 \mathrm{~m} \text { to } 0 \\
\text { at } 6 \mathrm{~m}) \text {; strobes ( } 5 \text { at } \\
1 \mathrm{~m} \text { to } 0 \text { at } 4 \mathrm{~m} \text { ) }\end{array}$ & $\begin{array}{l}\text { Coho hid when in ambient } \\
\text { daylight. At night, they } \\
\text { were still until exposed to } \\
\text { mercury or strobe lights; } \\
\text { they hid when exposed to } \\
\text { strobe lights and actively } \\
\text { swam with mercury lights. } \\
\text { No clear response was } \\
\text { noted under reversed } \\
\text { adaption. Chinook were } \\
\text { active (cruising or actively } \\
\text { milling) for all treatments } \\
\text { and adaptations. Chinook } \\
\text { salmon (adapted to } \\
\text { darkness) initially moved } \\
\text { toward the mercury light } \\
\text { when it was first turned on } \\
\text { but slowly retreated as the } \\
\text { intensity increased. } \\
\text { Reversals of ambient } \\
\text { lighting (darkening the } \\
\text { raceway during the day or } \\
\text { illuminating it at night) } \\
\text { had little effect on fish } \\
\text { behavior. }\end{array}$ \\
\hline
\end{tabular}




\begin{tabular}{|c|c|c|c|c|c|c|}
\hline Reference & Study Objectives & Species & Life Stage & Experimental Conditions & Light Intensity & Results \\
\hline $\begin{array}{l}\text { Novales-Flamarique I } \\
(2000)\end{array}$ & $\begin{array}{l}\text { To determine the ontogeny } \\
\text { of UV sensitivity }\end{array}$ & $\begin{array}{l}\text { Sockeye } \\
\text { salmon }\end{array}$ & $\begin{array}{l}\text { Alevin through } \\
\text { adult }\end{array}$ & $\begin{array}{l}\text { Wild sockeye alevins were } \\
\text { raised in tanks for } 4 \text { years } \\
\text { and were tested for UV } \\
\text { sensitivity. Fish were } \\
\text { adapted to a given back- } \\
\text { ground light for } 1 \mathrm{hr} \text {, after } \\
\text { which sensitivity was } \\
\text { assessed at wavelengths } \\
\text { from } 350 \text { to } 720 \text { nm. For a } \\
\text { given wavelength, light } \\
\text { intensity was increased in a } \\
\text { step-wise fashion and the } \\
\text { response measured. } \\
\text { Response consisted of ON } \\
\text { component (onset of light) } \\
\text { and OFF component (offset } \\
\text { of light). }\end{array}$ & & $\begin{array}{l}\text { UV sensitivity greatly } \\
\text { diminished in the smolt } \\
\text { stage but reappears in the } \\
\text { adult. UV cones disappear } \\
\text { from the dorsal and } \\
\text { temporal retina at the } \\
\text { smolt stage. }\end{array}$ \\
\hline $\begin{array}{l}\text { Novales-Flamarique I } \\
\text { (2005) }\end{array}$ & $\begin{array}{l}\text { Microspectrophotometry } \\
\text { and histological techniques } \\
\text { were used to characterize } \\
\text { the visual pigments and } \\
\text { photoreceptor types in three } \\
\text { species of Pacific salmon as } \\
\text { a function of time of year, } \\
\text { developmental stage, and } \\
\text { retinal location }\end{array}$ & $\begin{array}{l}\text { Coho salmon, } \\
\text { Chinook } \\
\text { salmon, chum } \\
\text { salmon }\end{array}$ & All life stages & $\begin{array}{l}\text { Hatchery-reared stock } \\
\text { raised either outdoors or } \\
\text { indoors. Indoor rearing } \\
\text { facilities had same } \\
\text { photoperiod regime as } \\
\text { outdoor but different } \\
\text { intensity and spectral } \\
\text { content. }\end{array}$ & & $\begin{array}{l}\text { All three species had cone } \\
\text { visual pigments with } \\
\text { maximum absorbance in } \\
\text { the UV, blue, green, and } \\
\text { red parts of the spectrum. } \\
\text { The yoke-sac alevin stage } \\
\text { did not have the blue } \\
\text { visual pigment. Smolts } \\
\text { had predominantly single } \\
\text { cones with blue visual } \\
\text { pigment. Coho and } \\
\text { Chinook smolts switched } \\
\text { from vitamin A1- to } \\
\text { vitamin A2-dominated } \\
\text { retina in the spring. Adult } \\
\text { spawners had vitamin } \\
\text { A2-dominated retina. The } \\
\text { central retina of all three } \\
\text { species had three types of } \\
\text { double cones (large, } \\
\text { medium, and small). } \\
\text { Temperature increases in } \\
\text { the spring correlated with } \\
\text { rises in porphyropsin. }\end{array}$ \\
\hline
\end{tabular}




\begin{tabular}{|c|c|c|c|c|c|c|}
\hline Reference & Study Objectives & Species & Life Stage & Experimental Conditions & Light Intensity & Results \\
\hline $\begin{array}{l}\text { Novales-Flamarique I and } \\
\text { HI Browman (2001) }\end{array}$ & $\begin{array}{l}\text { Test whether polarized light } \\
\text { improves prey location }\end{array}$ & Rainbow trout & $\begin{array}{l}\text { Mean length = } \\
1.55 \mathrm{~cm}\end{array}$ & $\begin{array}{l}\text { Three treatments: diffuse } \\
\text { white light; polarized white } \\
\text { light; and short-wavelength } \\
\text { light ( } 52 \% \text { to } 97 \% \\
\text { polarized). Prey location } \\
\text { distances were measured. }\end{array}$ & $\begin{array}{l}\text { White light: } 5.62 \mathrm{x} \\
10^{16} \text { photons } / \mathrm{m}^{2} / \mathrm{s} \text {; } \\
\text { short-wavelength } \\
\text { light: } 4.23 \times 10^{16} \\
\text { photons } / \mathrm{m}^{2} / \mathrm{s}\end{array}$ & $\begin{array}{l}\text { Prey location distances } \\
\text { were significantly longer } \\
\text { under white polarized light } \\
\text { compared to nonpolarized } \\
\text { light. Under short- } \\
\text { wavelength polarization, } \\
\text { distances were longer } \\
\text { under } 85 \% \text { and } 97 \% \\
\text { polarization than under } \\
52 \% \text { polarization. That is, } \\
\text { fish detected prey at } \\
\text { greater distances under } \\
\text { polarized light. }\end{array}$ \\
\hline $\begin{array}{l}\text { Novales-Flamarique I, } \\
\text { A Hendry, and } \\
\text { CW Hawryshyn (1992) }\end{array}$ & $\begin{array}{l}\text { Characterize the spectra of } \\
\text { available light in Lake } \\
\text { Cowichan, a nursery lake } \\
\text { for various salmonid species }\end{array}$ & None & & $\begin{array}{l}\text { Seven sampling stations } \\
\text { were established around the } \\
\text { lake; light was measured } \\
\text { using a LiCor spectro- } \\
\text { radiometer; measurements } \\
\text { were taken from a depth of } \\
18 \mathrm{~m} \text { to } 0.3 \mathrm{~m} \text { of the } \\
\text { surface at } 3 \text {-m intervals. }\end{array}$ & $\begin{array}{l}\text { UV light most } \\
\text { attenuated with } \\
\text { depth; near surface, } \\
\text { short-wavelengths } \\
\text { constitute a major } \\
\text { part of the light; with } \\
\text { increasing depths, the } \\
\text { maximum is at } \\
560 \text { nm (green); } \\
\text { during crepuscular } \\
\text { periods, there was an } \\
\text { increase toward } \\
\text { shorter wavelengths. }\end{array}$ & See light intensity. \\
\hline $\begin{array}{l}\text { Novales-Flamarique I, } \\
\text { S Hiebert, and J Sechrist } \\
\text { (2006) }\end{array}$ & $\begin{array}{l}\text { Assess whether strobo- } \\
\text { scopic illumination has any } \\
\text { effect on the visual system } \\
\text { of fish }\end{array}$ & $\begin{array}{l}\text { Kokanee and } \\
\text { sockeye }\end{array}$ & $\begin{array}{l}\text { Kokanee spawner; } \\
\text { sockeye smolt }\end{array}$ & $\begin{array}{l}\text { Fish were exposed to one } \\
\text { of three experimental } \\
\text { conditions: 1-min, } 5 \text {-min, } \\
\text { or 1-hr exposure to strobe } \\
\text { lights. }\end{array}$ & & $\begin{array}{l}\text { Overall, retinal } \\
\text { morphology and lens } \\
\text { appearance were similar } \\
\text { between controls and fish } \\
\text { exposed for } 1 \text { to } 5 \text { min. } \\
\text { Fish exposed for } 3 \mathrm{hr} \text { died. } \\
\text { Fish exposed to strobe } \\
\text { lights showed delayed } \\
\text { escape response to a } \\
\text { shadow stimulus. The } \\
\text { delay ranged from } 5 \text { min } \\
\text { for the } 1 \text {-min exposure to } \\
25 \text { min for the } 5 \text {-min } \\
\text { exposure. }\end{array}$ \\
\hline
\end{tabular}




\begin{tabular}{|c|c|c|c|c|c|c|}
\hline Reference & Study Objectives & Species & Life Stage & Experimental Conditions & Light Intensity & Results \\
\hline $\begin{array}{l}\text { Parkyn DC and } \\
\text { CW Hawryshyn (2000) }\end{array}$ & $\begin{array}{l}\text { Characterize and compare } \\
\text { daylight spectral and } \\
\text { polarization sensitivity in } \\
\text { salmonids }\end{array}$ & $\begin{array}{l}\text { Rainbow trout, } \\
\text { steelhead, } \\
\text { cutthroat trout, } \\
\text { kokanee, } \\
\text { brook char }\end{array}$ & Juvenile (parr) & $\begin{array}{l}\text { Recordings were made of } \\
\text { the optic nerve of fish } \\
\text { exposed to white-light } \\
\text { background conditions and } \\
\text { UV-isolating background } \\
\text { conditions. }\end{array}$ & $\begin{array}{l}\text { Two quartz/halogen } \\
\text { light channels fitted } \\
\text { with both a } 700-n m \\
\text { short-pass filter and } \\
2.0 \text { neutral-density } \\
\text { filter were used for } \\
\text { white-light condit- } \\
\text { ions; for UV back- } \\
\text { ground, tungsten } \\
\text { background with } \\
450 \text {-nm filter in one } \\
\text { channel and a } \\
550 \text {-nm filter in } \\
\text { second. }\end{array}$ & $\begin{array}{l}\text { Spectral response of } \\
\text { steelhead, rainbow, cut- } \\
\text { throat trout, and brook } \\
\text { char was dominated by the } \\
\text { red and green cone } \\
\text { mechanisms. The green } \\
\text { cone mechanism domi- } \\
\text { nated in kokanee } \\
\text { (ON-response). The } \\
\text { sensitivity of OFF- } \\
\text { responses was dominated } \\
\text { by green cone mechanisms } \\
\text { in all species. All species } \\
\text { were sensitive to UV } \\
\text { radiation. }\end{array}$ \\
\hline $\begin{array}{l}\text { Parkyn DC, JD Austin, } \\
\text { and CW Hawryshyn } \\
\text { (2003) }\end{array}$ & $\begin{array}{l}\text { To test whether hatchery- } \\
\text { reared rainbow trout would } \\
\text { orient to a plane-polarized } \\
\text { light; to compare orientation } \\
\text { responses of potamodromous } \\
\text { vs. anadromous salmonids; } \\
\text { and to examine the orienta- } \\
\text { tion response of laboratory- } \\
\text { trained rainbow trout relative } \\
\text { to natural polarized light }\end{array}$ & $\begin{array}{l}\text { Rainbow trout, } \\
\text { steelhead, } \\
\text { brook char }\end{array}$ & Juvenile & $\begin{array}{l}\text { Fish were trained using } \\
\text { operant conditioning } \\
\text { methodology }\end{array}$ & $\begin{array}{l}\text { 100-W tungsten- } \\
\text { halogen light with } \\
\text { UV-transmitting } \\
\text { optics }\end{array}$ & $\begin{array}{l}\text { Fish could be trained to } \\
\text { orient to polarized light; } \\
\text { however, untrained fish } \\
\text { did not orient to polarized } \\
\text { light. }\end{array}$ \\
\hline $\begin{array}{l}\text { Pauley GB, BM Bortz, } \\
\text { and MF Shepard (1986) }\end{array}$ & $\begin{array}{l}\text { The review is designed to } \\
\text { provide a brief, comprehen- } \\
\text { sive sketch of the biological } \\
\text { characteristics and environ- } \\
\text { mental requirements }\end{array}$ & Steelhead trout & All & & & \\
\hline $\begin{array}{l}\text { Pauley GB, Risher, and } \\
\text { GL Thomas (1989) }\end{array}$ & $\begin{array}{l}\text { The review is designed to } \\
\text { provide a brief, comprehen- } \\
\text { sive sketch of the biological } \\
\text { characteristics and environ- } \\
\text { mental requirements }\end{array}$ & Sockeye & All & & & \\
\hline
\end{tabular}




\begin{tabular}{|c|c|c|c|c|c|c|}
\hline Reference & Study Objectives & Species & Life Stage & Experimental Conditions & Light Intensity & Results \\
\hline $\begin{array}{l}\text { Puckett KJ and } \\
\text { JJ Anderson (1988) }\end{array}$ & $\begin{array}{l}\text { Test the response of fish to } \\
\text { different ratios of stimulus } \\
\text { light to adaptation light. }\end{array}$ & $\begin{array}{l}\text { Chinook } \\
\text { salmon }\end{array}$ & $\begin{array}{l}\text { Juvenile ( } 2 \text { months; } \\
\text { average length = } \\
53 \mathrm{~mm} \text { ) }\end{array}$ & $\begin{array}{l}15 \text { salmon were placed in } \\
\text { experimental tank at a } \\
\text { specific adaptation light } \\
\text { intensity. After } 20 \text { min, the } \\
\text { adaptation light was turned } \\
\text { off and the stimulus light } \\
\text { turned on. Fish behavior } \\
\text { was videotaped for } 2 \text { min. } \\
\text { There were } 6 \text { replicates of } \\
\text { each combination of } \\
\text { adaptation/stimulus light. }\end{array}$ & $\begin{array}{l}\text { Light intensity } \\
\text { (microeinsteins } / \mathrm{m}^{2} / \mathrm{s} \text { ): } \\
0.005 \text { to } 10 \text { for } \\
\text { stimulus light; } 0.1 \text { to } \\
1 \text { for adaptation light. } \\
\text { Adaptation light } \\
\text { provided by two } \\
100-W \text { incandescent } \\
\text { bulbs; stimulus light } \\
\text { consisted of a } 200-\text {, } \\
40-\text {, or } 15-W \text { bulb. }\end{array}$ & $\begin{array}{l}\text { Fish were attracted to } \\
\text { light, and the strength of } \\
\text { the attraction was propor- } \\
\text { tional to the logarithm of } \\
\text { the ratio of stimulus light } \\
\text { to adaptation light. The } \\
\text { relationship was pyra- } \\
\text { midal, with the strongest } \\
\text { attraction at a ratio of } 0 \text {. } \\
\text { When the stimulus light } \\
\text { was stronger than the } \\
\text { adaptation light, fish were } \\
\text { attracted to the dim zone } \\
\text { that bounded the light } \\
\text { spot. At the highest ratio } \\
\text { (100, where the stimulus } \\
\text { was } 100 \text { times more } \\
\text { intense than the adaptation } \\
\text { light), fish swam to the } \\
\text { farthest corner of the tank } \\
\text { and appeared to actively } \\
\text { avoid the light. }\end{array}$ \\
\hline Rainey WS (1985) & $\begin{array}{l}\text { Overview of the design of } \\
\text { juvenile bypass systems }\end{array}$ & & & & & $\begin{array}{l}\text { Juvenile salmonids } \\
\text { normally face upstream } \\
\text { during outmigration; } \\
\text { avoidance by juvenile fish } \\
\text { is based on visual } \\
\text { response, touch, or } \\
\text { perception of a changed } \\
\text { hydraulic condition. } \\
\text { Visual response is depend- } \\
\text { ent on time of day, water } \\
\text { turbidity, and turbulence. } \\
\text { Juveniles tend to resist } \\
\text { being drawn through dark } \\
\text { slots or conduits. }\end{array}$ \\
\hline
\end{tabular}




\begin{tabular}{|c|c|c|c|c|c|c|}
\hline Reference & Study Objectives & Species & Life Stage & Experimental Conditions & Light Intensity & Results \\
\hline Schilt CP (2007) & $\begin{array}{l}\text { Review of the progress to } \\
\text { develop bypass and protect } \\
\text { fish at hydropower dams on } \\
\text { the Snake and Columbia } \\
\text { rivers }\end{array}$ & & & & & $\begin{array}{l}\text { Juvenile salmonids pass } \\
\text { the large Columbia and } \\
\text { Snake River dams deep } \\
\text { (via turbine or spill bays) } \\
\text { at night and surface pas- } \\
\text { sage is generally higher } \\
\text { during the daytime. } \\
\text { Response to light is } \\
\text { limited by turbidity, which } \\
\text { is often high at mainstem } \\
\text { dams. Many factors act in } \\
\text { concert to determine the } \\
\text { response to a stimulus, } \\
\text { including season, time of } \\
\text { day, light levels, presence } \\
\text { of predators, distance to } \\
\text { cover, temperature, group } \\
\text { size, noise regime, current, } \\
\text { species, and even } \\
\text { subspecies. }\end{array}$ \\
\hline $\begin{array}{l}\text { Simenstad CA, } \\
\text { BJ Nightingale, } \\
\text { RM Thom, and } \\
\text { DK Shreffler (1999) }\end{array}$ & $\begin{array}{l}\text { Review the literature with } \\
\text { respect to the response of } \\
\text { juvenile salmon to light. } \\
\text { The review was looking at } \\
\text { probable impacts of ferry } \\
\text { terminals on migrating } \\
\text { salmonids. }\end{array}$ & & & & & $\begin{array}{l}\text { Extensive review of the } \\
\text { literature; used to access } \\
\text { articles not readily } \\
\text { available. }\end{array}$ \\
\hline
\end{tabular}




\begin{tabular}{|c|c|c|c|c|c|c|}
\hline Reference & Study Objectives & Species & Life Stage & Experimental Conditions & Light Intensity & Results \\
\hline $\begin{array}{l}\text { Tabor RA, GS Brown, } \\
\text { and VT Luiting (2004) }\end{array}$ & $\begin{array}{l}\text { Determine the effect of light } \\
\text { intensity on the migratory } \\
\text { behavior of sockeye salmon } \\
\text { fry and on the predation of } \\
\text { fry by cottids }\end{array}$ & $\begin{array}{l}\text { Sockeye } \\
\text { salmon }\end{array}$ & Fry & $\begin{array}{l}\text { Predation rates were } \\
\text { evaluated under six light } \\
\text { intensities in a circular tank } \\
\text { with minimum flow and } \\
\text { under four light intensities } \\
\text { in a flowing system. }\end{array}$ & $\begin{array}{l}\text { Circular tank: } 0.0 \text {, } \\
0.03,0.06,0.11,1.08 \text {, } \\
\text { and } 10.8 \text { lux. } \\
\text { Flowing system: } \\
0.00,0.22,1.08 \text {, and } \\
5.4 \text { lux }\end{array}$ & $\begin{array}{l}\text { In the flowing system, the } \\
\text { fry quickly passed through } \\
\text { the system under complete } \\
\text { darkness; as light intensity } \\
\text { increased, fewer fish } \\
\text { migrated and at a slower } \\
\text { speed. When predators } \\
\text { were present and light } \\
\text { intensity was high, even } \\
\text { fewer fry migrated, but } \\
\text { those that did swam at a } \\
\text { higher speed. In the field, } \\
\text { the shoreline abundance of } \\
\text { fry and predation by } \\
\text { cottids increased with } \\
\text { increasing light intensity. } \\
\text { When lights were turned } \\
\text { off, the abundance of fry } \\
\text { declined dramatically. }\end{array}$ \\
\hline Wert M (1988) & $\begin{array}{l}\text { Evaluate the effectiveness } \\
\text { of a passive pressure screen } \\
\text { bypass system under varied } \\
\text { conditions, including } \\
\text { lighting }\end{array}$ & $\begin{array}{l}\text { Rainbow trout, } \\
\text { coho salmon, } \\
\text { Chinook } \\
\text { salmon, and } \\
\text { steelhead trout }\end{array}$ & Smolt & $\begin{array}{l}\text { Fish were tested in the } \\
\text { bypass system using two } \\
\text { screen types, three angles } \\
\text { of inclination, and a variety } \\
\text { of inflow to bypass flow } \\
\text { ratios. Light was incidental } \\
\text { in that one side of the } \\
\text { bypass model was } \\
\text { constructed of clear } \\
\text { Plexiglas for viewing. }\end{array}$ & Not applicable & $\begin{array}{l}\text { During tests, it was } \\
\text { determined that } 70 \% \text { to } \\
90 \% \text { of the fish passed the } \\
\text { model close to the clear } \\
\text { front wall. When the } \\
\text { Plexiglas was covered } \\
\text { with opaque black plastic, } \\
\text { only } 48 \% \text { favored that side } \\
\text { of the model. }\end{array}$ \\
\hline
\end{tabular}




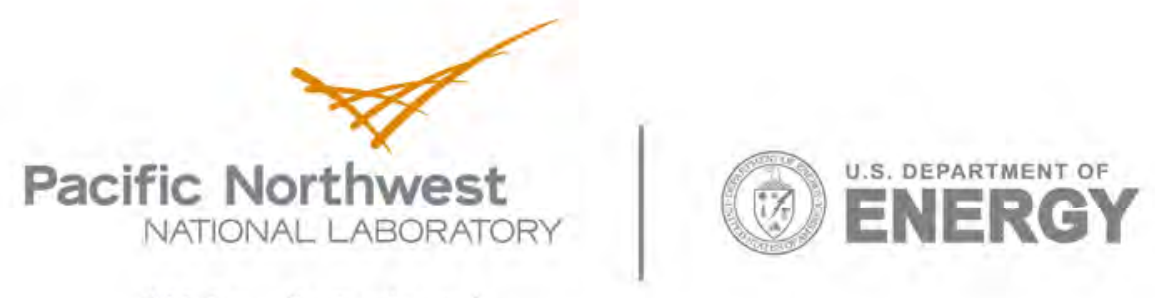

902 Battelle Boulevard

P.O. Box 999

Richland, WA 99352

1-888-375-PNNL (7665)

www.pnl.gov 